\title{
Kurumsal Sosyal Sorumluluk Bağlamında Modada Geri Dönüşüm ve Sürdürülebilirlik: Göstergebilimsel Bir Analiz
}

\author{
Eda Turancı (Dr. Öğr. Üyesi) \\ Ankara Hacı Bayram Veli Üniversitesi İletişim Fakültesi \\ eda.turanci@hbv.edu.tr
}

Başvuru Tarihi: 28.09.2020

Yayına Kabul Tarihi: 15.01.2021

Yayınlanma Tarihi: 29.01.2021

https://doi.org/10.17680/erciyesiletisim.801002

\section{Öz}

Tüketicilerin bilinç düzeyi, toplumsal farkındalıklar, artan çevresel hassasiyet, küresel ölçekli krizler, kaynakların hızla tükenmesine bağlı olarak geri dönüşüm anlayışının yaygınlaşması gibi unsurlar, kurumsal sosyal sorumluluk uygulamaları üzerinde etkili olmuştur. Moda sektörü, hammadde ihtiyacının yoğun olduğu ve çevre üzerinde önemli etkileri olan bir sektördür. Özellikle hazır giyim ve fast fashion (hızlı moda) endüstrisi, bir yandan tüketimin devam etmesine hizmet ederken bir yandan da sektörde, sürdürülebilirlik anlayışının yaygınlaştığı gözlemlenmektedir. Paradoksal bir ilişki gibi görülebilecek olan bu durum, özellikle moda sektöründe çevresel hareketlerin ve sosyal sorumluluk uygulamalarının artması ile kendini göstermektedir. Son yıllarda dikkat çeken H\&M “Kıyafet Toplama Programı-Modada Geri Dönüşüm” projesi, hem tüketimin devamlılığı, hem de geri dönüşümün arttırılması açısından önemlidir. Çalışmada H\&M markasının geri dönüşüm kampanyasına ait iki kampanya (reklam) filmi, göstergebilimsel yöntem aracılığıyla incelenmektedir. Bu çalışmanın temel sorunsalı örneklem olarak seçilen filmlerde hangi göstergeler ile sosyal sorumluluk, geri dönüşüm, çevresel duyarlılık ve sürdürülebilirlik anlayışının kodlandığını anlamaktır. Elde edilen bulgular çerçevesinde filmlerde, doğaya ilișkin göstergelerin sıkça kullanıldığı, kullanılan kıyafetlerin renk ve desenleriyle de bu göstergelerin desteklendiği, özgürlük, mutluluk, eğlence gibi temalara sıkça yer verildiği sonuçlarına varılmıştır.

Anahtar Kelimeler: Kurumsal Sosyal Sorumluluk, Moda, Geri Dönüşüm, Göstergebilim. 


\title{
Fashion Recycling and Sustainability in the Context of Corporate Social Responsibility: A Semiotic Analysis
}

\author{
Eda Turancı (Asst. Prof. Dr.) \\ Ankara Hacı Bayram Veli University Faculty of Communication \\ eda.turanci@hbv.edu.tr
}

Date Received: 28.09.2020

Date Accepted: 15.01.2021

Date Published: 29.01.2021

https://doi.org/10.17680/erciyesiletisim.801002

\begin{abstract}
Factors such as the level of consumer awareness, increased environmental sensitivity, global crises, the widespread understanding of recycling due to the rapid depletion of resources have influenced corporate social responsibility practices. The fashion sector is a sector where the need for raw materials is intense and has significant effects on the environment. Especially the ready-to-wear and fast fashion industry serves to continue consumption and on the other hand, the understanding of sustainability has become widespread in the sector. This situation, which can be seen as paradoxical, is manifested by the increase in environmental movements and social responsibility practices. H\&M's "Garment Collecting-Fashion Recycling" project is important in terms of both continuity of consumption and increasing recycling. In the study, two advertising films of H\&M's recycling campaign were examined through the semiotic method. The main problem is to understand which indicators coded for social responsibility, recycle, environmental awareness, and sustainability in the films. It has been concluded that the indicators related to nature are frequently used to establish the concept of recycling, that these indicators are supported with the colors and patterns of the clothes, and themes such as freedom, happiness, and entertainment are included.
\end{abstract}

Keywords: Corporate Social Responsibility, Fashion, Recycling, Semiotics. 


\section{Giriş}

Günümüzde hem bireylerin hem de şirketlerin çevresel ve ekolojik duyarlılıkları giderek artmakta, sürdürülebilirlik anlayıșı ise önem kazanmaktadır. Yaşanan küresel sorunlar, doğal kaynakların tükenmesi, yaşam alanlarında meydana gelen geri döndürülemez felaketler gibi durumlar bu duyarlılığın gelişmesinde rol oynarken, sanayileşmenin aktörleri olan sektörler de ekoloji ve çevre hakkında daha bilinçli hale gelmişlerdir. Özellikle moda sektörü, çevre ve doğal kaynaklar üzerinde olumsuz etkileri olan ve üretim sürecinde çeșitli kimyasalların kullanıldığı bir sektördür. Son yıllarda dikkat çeken "fast-fashion" (hızlı moda) anlayışı, tüketimi arttırması sebebiyle olumsuz çevresel etkileri pekiştirici niteliktedir. Bu sebeple moda sektörü ve hızlı moda sektörünün önemli markaları, kurumsal sosyal sorumluluk uygulamaları ile neden oldukları olumsuz etkileri geri döndürmek adına çeşitli girişimlerde bulunmaya başlamışlardır. Hayata geçirilen geri dönüşüm ve kıyafet toplama kampanyaları, çevreye duyarlı politikaların göstergesi olarak değerlendirilmektedir.

Moda, giyim, kuşam ve örtünme gibi işlevsel özelliklerinin ötesinde, sembolik açıdan da önemli bir göstergeler bütünüdür. Modaya ilişkin unsurlar, mesajın aktarımı açısından işlevseldir. Popüler hızlı moda markaları ise sembolik kodlarının inşasında önemli aktörlerdir. Bu markalar, bir yandan modanın akışını belirlerken bir yandan da sektörel projelerin öncüsü konumundadır. Son yıllarda -her ne kadar paradoksal bir ilişki gibi görülse de- hızlı moda markalarının geri dönüşüme önem veren projeleri dikkat çekmektedir. Çalıșmada hızlı moda markalarından biri olan H\&M'in "Kıyafet Toplama Programı-Modada Geri Dönüşüm” projesi kapsamındaki iki tanıtım/reklam filmi, göstergebilim yöntemiyle incelenecektir. Çalışmada amaçlanan, markanın sosyal sorumluluk, geri dönüşüm, çevresel duyarlılık ve sürdürülebilirlik anlayışının hangi göstergeler aracılığıyla sunulduğunu anlamaktır.

\section{Moda, Hazır Giyim ve Kurumsal Sosyal Sorumluluk}

Giyinme ve örtünme gibi temel anlamları çerçevesinde ele alındığında moda kavramının tarihsel olarak eskilere dayandığını söylemek mümkün olmakla birlikte, kavramın günümüzdeki anlamsal karşılığını edinmesi süreci, sanayileşme ve seri üretim gibi olgularla açıklanabilir. Moda, sadece giyim-kuşam ile ilgili bir kavram olmayıp, görünüşten yaşam tarzına, davranış kalıplarından yaşama ilişkin genel kabullere kadar, geniş bir çerçevede değerlendirilebilecek bir kavramdır.

Moda kavramı geniş anlamda belli bir döneme egemen olmuş ancak "belli başlı tarzdan daha çabuk değișen kültür ve yaşam biçimine ilişkin beğeniler bütünü” olarak, dar anlamda ise "giysi ve bağlantılı ürünlerin kesim, biçim, renk ve malzemesindeki her sezon yerini farklı biçimlere bırakan beğeni devreleri" (Çeliksap, 2015, s. 60) olarak tanımlanabilir. Barbarosoğlu, modaya ilişkin iki farklı görüș olduğunu söylemektedir. Modayı "kıyafet çeşitliliği" olarak gören, modanın eski çağlardan beri var olduğunu savunan birinci görüş, "modanın günümüzde en önemli karakteristiği sayılan biçimin bütün tabakalar tarafından giyilebilme özelliğini” eksik bırakmaktadır. İkinci görüş ise Sanayi Devrimi ile Fransız İhtilali'ni modanın başlangıcı olarak alır. Sanayi Devrimi'nin moda üzerindeki en önemli etkisi, dokuma sanayinin gelişmesi ve dikiş makinasının kullanılması gibi icatlar ile iplik ve kumaşların daha ucuza ve daha çok miktarlarda üretimidir (Barbarosoğlu, 2015, s. 28-29, 34). Bir başka tanımda ise, "giysilerin, tanımlanmış, belli bir döneme karşılık gelen karakteristik özelliğidir. 0 özelliğe uyan bir model moda sayılır" (Aktulum, 2019, s. 8) denilmektedir. 
Sanayi Devrimi'nin moda endüstrisi ile olan ilişkisi bir yana, sanayileşmenin, seri üretimin ve kitlesel tüketimin etkileri pek çok açıdan tartışılırken, bu gelişmelerin toplumsal, sosyolojik ve çevresel etkileri her geçen gün daha net gözlemlenmektedir. Özellikle kısıtlı kaynaklara bağlı olarak yapılan üretim ve bunun bir sonucu olarak kitlesel tüketim, yeni tartışmaları gündeme getirmiștir. Moda ve hazır giyim endüstrisi hammadde ihtiyacının yoğun olduğu bir sektördür. Aynı zamanda piyasadaki yoğun talebi karşılamak için sürekli üretim ihtiyacı da bulunmaktadır. Yoğun talebin karşılanmasında, sanayileşmenin olumlu etkileri olmakla birlikte makineleşmenin başta ekolojik olmak üzere sosyal ve toplumsal etkileri de çeşitli eleştirilere neden olmuştur.

Kozlowski'nin çalışmasında özetlediği gibi, Sanayi Devrimi'nden bu yana yaşanan gelişmeler, bugün yaşanan çevresel ve sosyal sorunların önemini arttırırken artan tüketim seviyesi, yenilenmeyen kaynakların kullanımı, iklim değişikliği, ekolojik sorunlar, hızlı moda ve düşük maliyetli hazır giyim sektörünün ortaya çıkışı gibi unsurlar, hazır giyim endüstrisini küresel çevre sorunlarının odağı haline getirmiştir. Bu durum ise markaların, çevresel ve sosyal açıdan daha sorumlu davranmalarına neden olmuştur. Giyim sektörü, sosyal sorumluluk anlayışlarını iyileștirme ve geliştirme yönünde artan bir endişe yaşamaya başlamış ve kurumsal sosyal sorumluluk çalışmaları, kısmen de olsa sorunlara bir çözüm olarak gündeme gelmiştir (Kozlowski, 2012).

Philip Kotler ve Nancy Lee (2016, s. 2-3) çalışmalarında kurumsal sosyal sorumluluğu, "toplumun refahını iyileştirmek için üstlenen bir yükümlülük" olarak tanımlarken toplum refahının hem insani değerler ile hem de çevresel konularla ilgili olduğunu vurgulamışlardır. Kurumsal sosyal sorumluluk, "işletmenin tüm paydaşlarının yaşam kalitesini iyileştirirken, etik davranmayı, doğal çevreyi korumayı ve ekonomik gelişmeye katkıda bulunmayı, sürekli bir amaç olarak" kabul edilmesi fikri (Uzkesici, 2005, s. 72) olarak tanımlanmaktadır. Özgen'in (2007, s. 1) ifadesiyle ise "toplumsal faydayı sağlama, toplumsal ödevleri yerine getirme gereği”dir. Buna göre kurumsal sosyal sorumluluk ile ifade edilmeye çalışılan, "sosyal politikaların geliştirilmesinde ve uygulanmasında devletler kadar şirketlerin de aktif rol almasıdır” (Deren van het Hof \& Hoştut, 2020, s. 3).

Kurumsal sosyal sorumluluk kavramının 1960'lı yıllarda ortaya çıktığı söylenirken, o yıllarda toplumsal ve çevresel hareketlerin hız kazanması ile sivil toplum örgütlerinin işletmeler üzerinde kurdukları baskı, işletmelerin faaliyetlerinin, etkinliklerinin ve toplumsal rollerinin sorgulanmaya başlamasıyla sonuçlanmıştır (Deren van het Hof \& Çabuk, 2011, s. 52). Buna göre, daha önceleri günümüzde olduğu kadar dikkat çekmeyen çevreye ve doğal kaynaklara ilişkin konular, çevresel sorunların giderek artmasına paralel olarak öne çıkmaya başlamıştır (Karalar \& Kiracı, 2011, s. 63). Ekolojik hassasiyetler her geçen gün artarak devam etmekte ve küresel düzeyde yaşanan krizler ve sorunlar, çevresel faktörlerin yaşamın tüm alanlarıyla nasıl bütünleşik olduğunu açıkça göstermektedir.

Tüketicilerin bilinç düzeyi, toplumsal farkındalıklar, ekolojik hassasiyet ile doğal kaynakların hızla tükenmesi gibi unsurlar, kurumların iş yapışları üzerinde de ciddi değişimlere neden olmuştur. Artan çevresel kirliliğin ve çevre bilincinin gelişmesinin bir sonucu olarak sürdürülebilirlik anlayışı moda endüstrisi için önemli hale gelmiş (Shen, 2014, s. 6236-6246) ve şirketler, çevreye karşı duyarlı davranmaları ve sosyal sorumluluklarını yerine getirmeleri açısından daha fazla baskı hissetmeye başlamışlardır (Bayraktaroğlu, Tanyeri, \& İlter, 2009, s. 66; Björklund, 2010, s. 340). Bununla bağlantılı olarak tekstil ve konfeksiyon sektörü; rekabet ortamı, uluslararası yasal ve yapısal düzenlemeler, müşteri bilincinin artması, istek ve beklentilerinin karşılanması, çalışan 
memnuniyeti, kar arttırma gibi nedenler dolayısıyla çeşitli sosyal sorumluluk projelerine ağırlık vermiş ve bu projeler, çevre ile ilgili uluslararası alıcılardan gelen baskılar doğrultusunda şekillenmiștir (Atılgan, Kanat, \& İlleez, 2011, s. 74).

Sosyal sorumluluk, çok boyutlu bir kavram olarak pek çok alanda uygulanabilir. Literatürde en çok başvurulan modellerden biri olan Carroll'ın (1979, s. 499) "Kurumsal Sosyal Sorumluluk Modeli", "ekonomik sorumluluklar, yasal sorumluluklar, ahlaki sorumluluklar, toplumsal sorumluluk (hayırseverlik, gönüllülük projeleri)" olmak üzere dört unsurdan oluşmaktadır (Peltekoğlu, 2018, s. 200). Bu sorumluluk alanlarının bazıları çeşitli dönemlerde öne çıkmakta ve kurumların varlıklarını borçlu oldukları toplumun o dönemdeki ihtiyaçları, sosyal sorumluluk uygulamalarının kapsamını belirleyebilmektedir.

Öte yandan Carroll'ın modelinden de anlaşılabileceği gibi temelde sosyal sorumluluk, bir kurum ya da kuruluşun sahip olması gereken bir bilinci ve anlayıșı yansıtmaktadır. Kurumsal sosyal sorumluluk kampanyaları ise bu anlayışın somut çıktıları olmakla birlikte sorumluluk duygusu ve bilinci, kurumun tüm eylemlerinde görünür olması gereken bir ilkedir. Gürel Boran'ın (2016, s. 49-50) açıkladı̆̆ gibi kurumların, çevreyi korumak, güvenilir ürünler sunmak, çalışanlar arasında cinsiyet ayrımı yapmamak gibi temel hak ve özgürlükleri korumak, adil ücret politikaları geliştirerek çalışanın sömürülmesini önlemek, çocuk işçi çalıştırmak gibi yasal olmayan uygulamalardan kaçınmak ve yasalara uygun davranmak, toplum refahını gözetmek gibi sorumlulukları bulunmaktadır. Deren van het Hof ve Hoştut'un (2020, s. 27) açıklamasıyla, şirketin örgütsel kimliğini ve kültürünü yansıtan sosyal sorumluluk anlayışı bir şirket politikası olarak değerlendirilmesi gereken yönetsel kararların bir parçasıdır. Aynı zamanda Özgen'in (2007, s. 2-3) çalışmasında da açıç̧a belirttiği gibi kurumsal sosyal sorumluluk "yasalara uymayı, faaliyetlerinin sonuçlarının sorumluluğunu almayı ve sürdürülebilir kalkınmaya katkıda bulunmayı içeren kapsamlı bir alandır".

Sosyal sorumluluğa ilişkin uygulama alanları, uluslararası alanda belirlenmiş küresel standartların sağlanmasıyla da ilgilidir. Bu doğrultuda Birlemiş Milletler Küresel İlkeler Sözleşmesi (Global Compact Türkiye, 2020a), uluslararası standartlarda belirlenmiş ilkeleri ile üyelerine "dünyanın en büyük kurumsal sürdürülebilirlik girişiminin bir parçası olma fırsatı vermektedir". Bu açıdan bakıldığında "insan hakları, çalışma standartları, çevre ve yolsuzlukla mücadele" başlıkları altında belirlenmiş 10 ilke, iş dünyasının temel sorumluluk alanlarına dikkat çekmektedir (Global Compact Türkiye, 2020b). Ek olarak, Birleşmiş Milletler Kalkına Programı (UNDP Turkey, 2020a) kapsamında belirlenen "Sürdürülebilir Kalkınma Amaçları" da 17 temel amaçtan oluşurken, bu amaçlardan bazıları "gezegeni korumak" ile ilgilidir. Bu doğrultuda iklim değişikliği, sürdürülebilir tüketim, çevre sorunları karşısında benimsenecek ilkeler gibi pek çok konuya dikkat çekilen program aslında "evrensel bir eylem çağrısı" olarak tanımlanmaktadır (UNDP Turkey, 2020b).

Günümüzde toplumun kalkınmasına destek olmak amacıyla kurumların ürün ve hizmetlerini, hesap verebilirliği, yasalarla uyumu ve toplum yararını gözeterek geliștirmeleri ve sunmaları başlıca görevleri arasındadır (Gürel Boran, 2016, s. 17). Türkiye Tekstil ve Hazırgiyim Sektöründe Kurumsal Sosyal Sorumluluk Durum Raporu'na (2012, s. 11) göre ise, tekstil ve hazır giyim sektörünün çevre üzerindeki etkileri "doğal liflerin yetiştirilmesinde kullanılan ilaçlar ve sentetik liflerin üretimindeki emisyonlarla başlamaktadır" ve bu noktadan sonra pek çok kimyasal kullanılmakta ve kirliliğine neden 
olacak atıklar söz konusu olmaktadır. Moda endüstrisinin ve hazır giyim sektörünün bahsedilen çevresel etkileri dikkate alındığında, bu sektörde geliştirilecek sosyal sorumluluk anlayışının önemi daha da anlaşılır olmaktadır.

\section{Fast-Fashion: İşlevin Ötesindeki Anlamlar}

Moda endüstrisi, sanayileşmenin getirdiği teknik olanaklara bağlı olarak seri üretimine dayanan bir sektör olmasının yanı sıra hızlı üretim süreçleri, günümüzde moda olan şeylerin de daha hızlı tüketilmesini sağlayan bir sistem yaratmıştır. Hazır giyim sektörü hızla dönüşen dünyaya ayak uydururken, kendisi de çok hızlı bir biçimde dönüşmekte ve her an yeni bir moda akımıyla tüketici karşısındaki yerini almaktadır. Bu sürecin bir parçası olarak "fast fashion" (hızlı moda) anlayışı, bir yandan son moda kıyafetlerin uygun fiyatlarla tüketiciyle buluşmasını sağlarken, bir yandan da markaların neredeyse haftalık kreasyonlar oluşturduğu bir düzene işaret etmektedir. Aynı zamanda bu anlayıș, ürünlerin de kullanım ömrünü kısaltarak daha hızlı tüketilmelerine yol açmakta ve bu nedenle yerlerine yenisinin gelmesine duyulan ihtiyacı da sürekli olarak beslemektedir. Ancak burada, işlevsel tüketimden ziyade sembolik bir tüketimden bahsedilmektedir. Ürünün işlevini yitirmesi ya da tükenmesinden öte, sembolik değerlerinin kaybolması veya hızlı bir biçimde "demode" olması söz konusudur.

"Fast fashion" kavramı, "1990’ların sonlarında modadaki hızlı değişimi anlatmak ve bazı şirketlerin bağlı kalmaya başladığı tüketim biçimini karakterize etmek" (Buzzo \& Abreu, 2019, s. 1) amacıyla kullanılmıştır. Modern moda anlayışıyla bağlantılı olarak günümüzde yaygın olan bu anlayış, geleneksel ve modern kıyafetin özellikleri çerçevesinde açıklanabilir. Barbarosoğlu'na göre geleneksel kıyafetler statü sembolüyken, alt sınıfların üst sınıfların kıyafetlerini taklit etmesi söz konusu değildir. Kıyafetlerin özellikleri iklim şartlarıyla ilgilidir ve bu nedenle giyim tarzında bölgesel farklılıklar söz konusudur. Geleneksel kıyafetler uzun yıllar değişmeden varlığını sürdürürken üretimleri büyük oranda el işçiliğine dayanmaktadır. Bunun karşısında ise modern kıyafetler, "ast-üst ilişkisine" dayanmamakta, alt sınıflar üst sınıfların giyimini taklit edebilmektedir. Modern kıyafetlerde ilkim koşullarına uygunluk aranmadığı gibi bir kıyafetin her türlü mevsimsel koşulda giyilebilmesi mümkündür. Son olarak geleneksel kıyafetlerin aksine çok hızlı ve kısa periyodlarla değişime uğrayan modern kıyafetler seri üretim anlayışıyla üretilmektedir (Barbarosoğlu, 2015, s. 23-24).

$\mathrm{Bu}$ açıklamalar ışığında, hızlı modanın sürekli ve kesintisiz bir tüketime dayandığı görülebilir. Sürekli tüketim mantığının ise toplumsal, ekonomik, sosyal ve çevresel pek çok etkisi bulunmaktadır. Binet ve diğerlerinin (2019, s. 19) dikkat çektikleri gibi hızlı moda, hem gezegenimiz hem de insanlar üzerinde büyük sorunlara neden olurken aynı zamanda "sürdürülemez talep ile büyük bir tüketime yol açmıştır". Moda söz konusu olduğunda, tüketilen şeylerin yalnızca nesneler olmadığı aşikardır.

Moda; görünüş, kıyafet, giyim, örtünme gibi unsurlar üzerinden tartışılırken, modanın bu kadar ön planda olmasının bir sebebi de, modanın ve bununla bağlantılı olarak kıyafetlerin işlevlerinin ötesindeki anlamlarıdır. Sembolik olarak pek çok mesaj barındıran görünüş ve giyim, kodların ve değerlerin aktarımını içermektedir ve bu kapsamda giysileri bir "iletişim dizgesi" (Ruşan, 2019) olarak değerlendirmek de mümkündür. Özellikle hızlı moda endüstrisinin markaları, sembollerin ve değerlerin inşası sürecinde etkili birer aktördürler. Barthes'ın çalışmasından aktarıldığı gibi bireylere belirli bir imaj sağlayan bu markalar, "bir yanda giysileri, diğer yanda dünyayı" (Waquet \& Laporte, 2011, s. 8) düzenlemektedir ve Barthes'e göre "moda dizgesi bir anlamlandırma sürecidir" (İnal, 
2003, s. 19). Aynı zamanda Batı'nın (2007, s. 6) da belirttiği gibi, markalar da birer kültürel göstergedir. $\mathrm{Bu}$ doğrultuda modanın, giysilerin ve kıyafetlerin taşıdıkların anlamları keşfetmek, sembolik anlamları görebilmek açısından oldukça önemlidir.

\section{Sürdürülebilirlik ve Modada Geri Dönüşüm: Getir, Değiştir, Kullan}

Son yıllarda her alanda "sürdürülebilirlik" anlayıșının öne çıktığı görülmektedir. Sürdürülebilirlik genellikle "kurumsal sosyal sorumlulukla eșleștirilir" (Joy, Sherry Jr. , Venkatesh, Wang, \& Chan, 2012, s. 274). Kozlowski kavramın, "çevre, ekonomi ve toplum" olmak üzere üç boyutta tanımlandığını belirtirken (2012, s. 21) sürdürülebilirlik, "hem küresel hem de yerel olarak ekolojik, ekonomik ve sosyo-politik boyutları kesişen, insanın geçimini ve refahını etkileyen karmaşık ve değişen çevresel dinamikleri içerir" (Joy, Sherry Jr. , Venkatesh, Wang, \& Chan, 2012, s. 274). Sürdürülebilirlik "kaynakların en az kullanımıyla, en faydalı sonucu elde etmek amacıyla yapılan uygulama ve planlamalardır" (Koca, Öz, \& Yıldırım Artaç, 2016, s. 220). Bu doğrultuda çevrenin korunması için, bu üç boyut (çevre, ekonomi, toplum) arasındaki dengenin önemine dikkat çekilebilir ve bu dengenin dikkate alındığı alanlardan biri de modadır.

Sürdürülebilir moda, "çevreci, geri dönüştürülebilir, yüksek kaliteli ürünlerin yer aldığı moda akımı" olarak açıklanırken sürdürülebilir moda ile amaçlanan "hızlı moda akımının neden olduğu hızlı tüketim davranışının yavaşlatılması ve ekolojik, sosyal ve ekonomik sürdürülebilirliğin sağlanmasıdır" (Gürcüm \& Yüksel, 2011, s. 48, 50). Çevre bilincinin artmasıyla, moda sektöründe sürdürülebilirlik ve sosyal sorumluluk anlayışlarının yaygınlaştığı görülmektedir (Koca, Öz, \& Yıldırım Artaç, 2016, s. 221). Sürdürülebilirlik, doğal ürünlerin üretilmesi, kullanılması, kullanım sürelerinin uzun olması ve geri dönüşümün gerçekleştirilmesiyle ilgilidir (Can \& Ayvaz, 2017, s. 110). Ancak, sürdürülebilir modaya ilişkin çeşitli eleştiriler de mevcuttur.

Gürcüm ve Yüksel'e (2011, s. 50) göre "sürdürülebilir moda paradokslarla doludur". Açıkladıkları gibi moda, "temelde sezonluk ve hızlı değișen eğilimlerle ilgilidir. Sürdürülebilirlik ise tanım olarak uzun sürmek anlamına gelmektedir. Sürdürülebilir moda, "modanın hızlı olan rutinine aykırı olmayı ve tüketim çılgınlığına katılmayı reddetmek anlamına gelmektedir" (Gürcüm \& Yüksel, 2011, s. 50). Can ve Ayvaz (2017, s. 115) da moda ve sürdürülebilirlik arasındaki çelişkiye dikkat çekmektedirler. Onlara göre sürdürülebilir modanın temel amacı, "süresiz olarak devam ettirilebilir sistemler oluşturmak ve çevrecilik ile sosyal sorumluluk ilkelerine uygun hareket etmektir". Buradaki temel çelişki, hızlı moda endüstrisinin bireyleri sürekli olarak tüketime yönlendiren doğasında yatmaktadır. Tüketim, bir yandan da kaynakların kullanımı anlamına gelmektedir. Ancak her ne kadar çeşitli eleştiriler olsa da moda endüstrisinin giderek daha çok benimsediği geri dönüşüm ve sürdürülebilirlik politikalarl, doğal kaynakların kullanım oranını düşürmektedir. "Herhangi bir tekstil ürününün toplanıp sınıflandırılması sırasında harcanan enerjinin, yeni bir ürün yapmaya göre 10 ila 20 kat daha az olduğu" (Göksel \& Yanmaz, 2011, s. 34) söylenmektedir.

\section{H\&M ve Sürdürülebilirlik Politikası}

Moda sektöründe sürdürülebilirliğin önemini kabul ederek çevre dostu uygulamaları tedarik zincirine dahil eden firmalar arasında H\&M de yer almaktadır (Shen, 2014, s. 6237). Bu anlayışla H\&M, 2001 yılından beri Birleşmiş Milletler Küresel İlkeler Sözleşmesi'nin de üyesidir (UN Global Compact, 2020b). Sürdürülebilir tasarımın bir ayağının, kıyafetlerin yeniden tasarlanmasıyla ve atık miktarlarının azaltılmasıyla ilgili olduğu ve H\&M gibi markaların bu tür üretimler yaptığı belirtilmektedir (Gürcüm \& 
Yüksel, 2011, s. 51). Nike, GAP, Levi Strauss, Marks \& Spencer, H\&M, Puma gibi birçok firmanın sıfır atık anlayışıyla ürünlerinin çevreye verdiği zararı azaltmaya çabaladıkları söylenmektedir (Mangır, 2016, s. 147). Çevreye olan etkilerini azaltmak ve olumlu bir marka imajı yaratmak için markaların, sürdürülebilir moda koleksiyonlarına giderek daha fazla yatırım yaptıkları ifade edilmektedir (Shen, Zheng, Chow, \& Chow, 2014, s. 971). Kozlowski (2012, s. 10) H\&M, Nike, Levi's ve Zara gibi markaların, organik pamuk ve geri dönüştürülmüş polyester gibi çevre açısından tercih edilen malzemeleri kullandıklarından bahsetmektedir.

H\&M (2020a) internet sitesinde, "Bir ürünün sürdürülebilirliğinden bahsederken, bu ürünün hem çevreye hem de onu yapan, hazırlayan, taşıyan, satan ve satın alan insanlara olan etkisinden söz ediyoruz!" ifadelerine yer verilmiştir. Atılgan ve diğerlerinin (2011) özetledikleri gibi H\&M'in "atık yönetim" ile "geri dönüşüm" düzenlemeleri kapsamında uygulamaları bulunmaktadır. Marka, ambalajların ve askıların geri dönüștürülmesine, geri dönüştürülmüş malzemelerin kullanımına, geri dönüşümün arttırılmasına odaklanmakta ve atığı, kimyasal kullanımını ve su tüketimini en aza indirmenin yollarını aramaktadır. Aynı zamanda marka 2010 yılından beri doğal kaynakları sorumlu biçimde kullanma bilinciyle en büyük organik pamuk kullanıcısı olmuştur (Atılgan, Kanat, \& İlleez, 2011, s. 76). 2013 yılında ise H\&M (2017a) dünya çapında konfeksiyon toplama girişimini başlatmıştır. Markanın Conscious koleksiyonu, dönüştürülebilir malzemeler kullanılarak üretilmektedir.

“H\&M Group Sustainability Report 2017” adlı raporda, sürdürülebilir modanın, "bugün, yarın ve gelecek nesiller için" erişilebilir olması gerektiğine inandıkları belirtilmektedir. Rapora göre 2017 yılında, üretimlerden kaynaklanan emisyonlar 2016 yılına göre \%21 azaltılmıştır ve hedef, 2030 yılına kadar \%100 geri dönüşümlü malzemelerin kullanılmasıdır (H\&M, 2017b, s. 7, 27). Aynı raporda markanın bugün kullandığı pamuğun \%59'unun sürdürülebilir olduğu, hedeflerinin ise 2020 yılına kadar \%100 sürdürülebilir kaynaklı pamuk kullanmak olduğu açıklanmıştır (H\&M, 2017b, s. 8). İncelenen "Kıyafet Toplama Programı-Modada Geri Dönüşüm” projesi sürdürülebilir moda anlayışının bir parçasıdır ve şu şekilde işlemektedir:

\footnotetext{
"Yeniden Giy: Tekrar giyilebilen klyafetler tüm dünyada ikinci el ürün olarak pazarlanır.

Tekrar kullan: Artık giyilmesi mümkün olmayan kumaşlar temizlik bezi gibi diğer ürünlere dönüştürülür.

Geri dönüștür: Tekrar kullanılamayan kumașlar tekstil lifi olarak ikinci bir şans elde eder ya da otomatik endüstrisine yönelik yalıtım ve nemlendirme amaçlı malzemelerin üretiminde kullanılır. Toplanan kıyafetlerden elde edilen gelirin tamamı tekstil geri dönüşüm araştırmalarına ve sosyal sorumluluk projelerine bağışlanır." (H\&M, 2020b)
}

Kampanya kapsamında kullanılmayan giysilerle dolu bir poşetin mağazalarda yer alan geri dönüşüm kutularına bırakılması durumunda, her torba başına müşteriye bir sonraki alışveriște kullanılmak üzere indirim kuponu verilmektedir. 2017 H\&M Sürdürülebilirlik Raporu'nda da belirtildiği gibi, 2017 yılında bu girişimden toplam 17.771 ton tekstil toplanmıștır (H\&M, 2017b, s. 8, 27). Verilen ödül ise, tüketicinin teşvik edilmesi olarak görülebilir (Shen, 2014, s. 6241). İndirim kuponu marka ve tüketiciler açısından "kazan-kazan" olarak değerlendirilmektedir. Kullanmadıkları ürünlerden kurtulan tüketiciler kampanyayla hem indirim kuponu kazanmakta, hem de geri dönüşüme katkı sağlamaktadırlar. 


\section{Yöntem}

Modanın, özelde giysi ve klyafetlerin, göstergeler ve sembolik anlamlarla ilişkili olduğunu ve bir iletişim ile anlam-mesaj aktarım aracı olarak ele alınabileceğini söylemek mümkündür (Barnard, 2002; Gençtürk-Hızal, 2003). Fiske'nin (2003, s. 63) açıklamasıyla gösterge, "kendisinden başka bir şeye gönderme yapan, duygularımızla kavrayabileceğimiz fiziksel bir şeydir ve varlığı, kullanıcıların onu bir gösterge olarak kabul etmelerine bağlıdır". Nitel araştırma yöntemlerinden olan göstergebilim ise, "göstergelere ve onların çalıșma biçimlerine" odaklanır (Fiske, 2003, s. 62). "Göstergebilimcilerce sürdürülen ortak bir tutuma göre moda da bir dildir" ve her bir kıyafet metaforik olarak bir metin gibi değerlendirilebilir (Aktulum, 2019, s. 1, 4). Bu anlamda aynı bir metni okur gibi kıyafetlerin de ne söylediğini dinlemek ya da okumak, pek çok mesaja erişimi mümkün kılacaktır.

Literatürde başta Charles Sanders Pierce ve Ferdinand de Saussure olmak üzere, Roland Barthes, Umberto Eco, A. Julien Greimas, Vladimir Propp gibi pek çok düşünürün göstergebilime ilişkin çalışmalarına rastlamak mümkünken bazı düşünürler moda konusuyla da ilgilenmişlerdir. Örneğin Barthes (1990), moda ve göstergeler arasındaki ilişkiye dikkat çekerek Fransa'daki moda dergilerinin dilini ayrıntılı olarak göstergebilim yöntemiyle incelemiştir. Barthes'ın çalışmasında moda söyleminden bahsettiği ifade edilmiş ve bu nedenle "doğrudan moda yerine moda üzerine kimi dergilerde yazılmış kısa yazıları" çözümlediği vurgulanmıştır (Aktulum, 2019, s. 7). Barthes'in amacının, söyleminin içinde düzenlendiği dilsel sistemi anlamak olduğu söylenebilir. Ek olarak Aktulum (2019, s. 11) çalışmasında Umberto Eco'ya gönderme yaparak, moda ve göstergeler hakkında şu ifadeleri kullanmıştır: “Herkesin nesneleri gördüğü yerde göstergebilimcinin gördüğü göstergelerdir' diyen Umberto Eco'nun tanımlamasına göre, bir bildiri aktarmak ereği olan her giysi istemli bir göstergedir. [...] Dolayısıyla, moda ve iletişim iç içedir".

Çalışmada örneklem olarak seçilen kampanya tanıtım/reklam filmleri hem Saussure'un anlamsal öğeleri olan "gösterge, gösteren ve gösterilen" bağlamında, hem de Barthes'ın anlamlandırma süreciyle işaret ettiği "düz anlam" ve "yan anlam" bağlamında incelenecektir. Barthes'in (1986, s. 35) açıkladığı gibi Saussure terminolojisine göre "gösteren ve gösterilen, göstergenin bileșenleridir". Gösteren "göstergenin fiziksel varlığ ya da maddi bileşeni", gösterilen ise "zihinsel kavram ya da gösterenin ima ettiği/işaret ettiği kavram ya da fikir" (Bauer \& Gaskell, 2000, s. 365) (Fiske, 2003, s. 67) olarak açıklanabilir. Ek olarak Barthes'ın (1986, s. 89-94) düz ve yan anlam kavramlarını da açıklamak gerekir. Düz anlam, kavramın, cümlenin ya da sözün "birinci dereceden ifadesidir, ifadeyi oluşturan kelimelerin gerçek anlamını ilgilendiren" (Yan \& Ming, 2015, s. 60) bir anlamdır. Chandler'a göre düz anlam, "bir göstergenin tanımlayıcı, gerçek ve açık" anlamıdır. Yan anlam ise, "göstergenin, sosyo-kültürel ve kişisel (ideolojik, duygusal vb.) anlamlarına" işaret eder ve böylece "bağlama bağlıdır" (Chandler, 2007, s. 137138). Danesi (2002, s. 220) yan anlamı, "göstergenin ikincil ya da sembolik anlamı" olarak açıklamıştır.

Açıklandığı gibi modanın çevre üzerindeki etkileri dikkate alındığında son yıllarda markaların çevreyi dikkate alan ve doğal kaynakların kullanımını azaltmayı amaçlayan kurumsal sosyal sorumluluk kampanyalarının önce çıtığı görülmektedir. Çalışmanın temel sorunsalı, moda endüstrisinin sosyal sorumluluk, çevresel duyarlılık ve sürdürülebilirlik anlayışlarını hangi göstergeler üzerinden oluşturduklarını anlamaktır. Bu doğrultuda H\&M'in “Modada Geri Dönüşüm” sosyal sorumluluk projesinin iki tanıtım/ 
reklam filmi göstergebilim yöntemiyle incelenerek markanın sorumluluk anlayışını hangi göstergeler ile kodladığı anlaşılmaya çalıșılacaktır. Çalışmada hızlı moda endüstrisinin önemli temsilcilerinden biri olan H\&M örneklem olarak seçilmiş ve markanın kiyafet geri dönüşüm kampanyası bu seçim açısından belirleyici olmuştur. Çalışmada şu sorulara cevap aranacaktır; "Filmlerde yer verilen göstergeler nelerdir? Bunlar hangi gösterenler ile sunulmuştur ve bu gösterenler ile gösterilen nedir? Aslında ne anlatılmak istenmektedir? Markanın sosyal sorumluluk anlayışı ve çevresel hassasiyetleri hangi göstergeler ile yansıtılmıştır? Filmlerde yer alan göstergelerin yan anlamları nelerdir?” Çalıșmada aynı zamanda sürekli tüketme anlayışına dayanan hızlı moda sektörü ile çevresel hassasiyet ve geri dönüşüm anlayışı arasındaki paradoksal ilişkinin nasıl kurulmaya çalışıldığı da sorgulanacaktır.

\section{Bulgular \\ H\&M "Bring it on (2017)"}

İnternet sitesinde yer alan bilgilere göre, Crystal Moselle`nin yönettiği filmin 26 Ocak 2017 yılında hm.com'da yayınlanmasıyla giysi toplama kampanyası "Bring It" başlamıştır. Kampanya, giysi geri dönüşümünün önemi konusunda farkındalık yaratmayı amaçlarken filmde giysilerin mağazalarda toplandıktan sonraki yolculukları anlatılmaktadır (H\&M, 2017a). Youtube hesabından erişim sağlanabilen film bir dakika otuz sekiz saniyedir ve araştırmanın yapıldığı tarihe kadar yaklaşık olarak 60 bin kere görüntülenmiştir.

Film bir partide başlar, arkada dans eden insanların olduğu görülür ve hafif karanlık bir ortamda markanın logosu büyük harfler ile ekranın ortasında yer almaktadır. Her şeyden önce bu, markanın konumlandırmasına ilişkin bir göndermedir. H\&M özellikle genç nesil arasında oldukça popüler olan markalardan biridir ve koleksiyonları günümüz trendlerine ve modaya yön veren dikkat çekici parçalar içermektedir. Parti göstergesi eğlence, hareket, dinamizm, gençlik gibi unsurlarla bağdaştırılmaktadır. Filmin ilk sahnesinin partide geçmesinin, marka konumlandırması ile ilişkili olduğu ve hedef kitlesine verdiği mesaj açısından da dikkat çekici olduğu düşünülmektedir. Logo ise, mesaja atılan imza niteliğindedir. Filmin ilk cümlesi "Haydi getir" olarak tercüme edilebilir ve filmin temel amacını yansıtan bir cümledir. Kampanyanın da adı olan bu cümle, ikinci bir imza niteliğindedir.

İlk sahnelerde insanların ve bir kadının dans ettiği görülmektedir. Kadının külotlu çorabının baş parmak kısmı kaçmıştır ancak yine de özgüvenli bir biçimde dans etmekte, hatta çeşitli hareketler ile kalabalıktan ayrışmaktadır. Kadının ayağında ayakkabı yoktur. Yırtık çorabına rağmen herhangi bir çekince göstermeden ayakkabısız olarak dans etmeye devam etmektedir. Göstergeler incelendiğinde özgürlük, mutluluk, eğlence, kendine güvenme gibi mesajların işlendiği görülmektedir. Kaçlk çorap, insanların saklamak istedikleri mahrem bir an gibi tanımlanabilir. Ayakkabı çıkarıldığında ortaya çıkan yırtık ya da eskimiş çorap, gizli, mahrem ya da rahatsızlık verici bir durumun gözler önüne serilmesi gibidir. Ancak çorabı kaçmış kadın, bu duruma hiç aldırış etmeden özgüvenli bir şekilde eğlenmektedir (Şekil 1, Şekil 2, Tablo 1). 


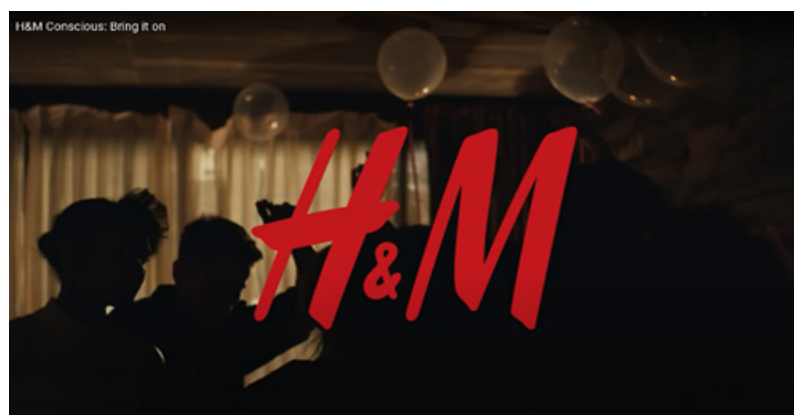

Şekil 1.
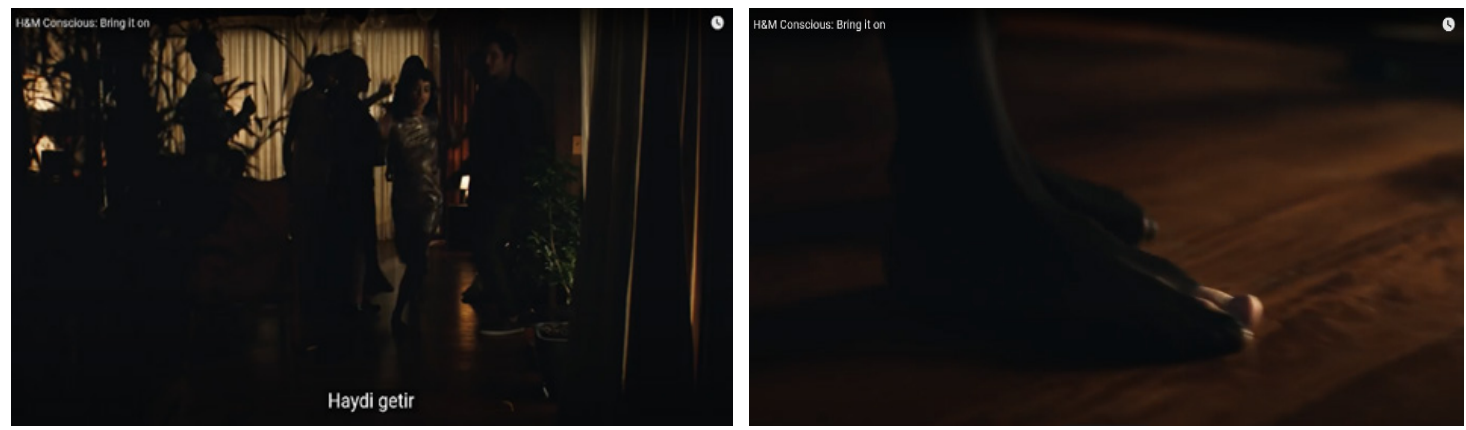

Şekil 2.

Tablo 1. Sekil 1 ve Șekil 2 Analizi

\begin{tabular}{|l|l|l|l|}
\hline Gösterge & Gösteren & Gösterilen & Yan anlam \\
\hline İnsan & Kadın & Dans eden kadın & $\begin{array}{l}\text { Dans, eğlence, özgürlük, mutluluk, iyi zaman } \\
\text { geçirme ile ilgilidir. Kadının kendisini sahnenin } \\
\text { ortasına atması özgüveni sembolize eder. Kadın, } \\
\text { kaçık çorabına rağmen kimsenin ne düşündüğünü } \\
\text { umursamadan istediği gibi hareket etmektedir. }\end{array}$ \\
\hline Nesne & Balon & Parti / Kutlama & $\begin{array}{l}\text { Balonlar sembolik olarak özgürlüğün işareti } \\
\text { olarak kabul edilebilir. Balon aynı zamanda, } \\
\text { kutlama ve parti ile ilgilidir. Eğlence, dinamizm } \\
\text { ve hareket temaları işlenmektedir. }\end{array}$ \\
\hline Nesne & Çorap & Kaçık çorap & $\begin{array}{l}\text { Kaçık çorap, saklamak istediğimiz durumlara işaret } \\
\text { ederken kaçık çorabın görünmesi, kimsenin görmesini } \\
\text { istemediğimiz kusurları korkmadan sergilemek, } \\
\text { umursamamak, dilediğince davranmak ile ilgilidir. }\end{array}$ \\
\hline Yazı & Harfler & Markanın logosu & $\begin{array}{l}\text { Markanın logosu, filme atılan imzadır. Filmin } \\
\text { kime ait olduğunu belirten bir göstergedir. }\end{array}$ \\
\hline
\end{tabular}

Bu sahnelerden sonra filmde sırasıyla şu sahneler görülmektedir. Bir restoranda genç bir çift yemek yerken şakalaşmaktadır ve bir anda erkeğin önünde duran yemek olduğu gibi üstüne dökülür. Ancak bu durum karşısında çift kahkahalarla gülerken, erkeğin üstündeki tişört tamamen yemek lekesi olmuştur. Bir kadın, altında eskimiş iç çamaşırı ve üstünde tişört ile odasında aynaya bakarken görülmektedir. Sadece teki kalmış bir çorap, sahibi görülmeyen bir el tarafından fırlatılmaktadır. Kırmızı elbiseli bir kadının suyun içinde -göl kadar durgun bir suyun içinde- sırt üstü durduğu görülmekte ve yüzünde huzurlu bir ifade bulunmaktadır (Şekil 3, Tablo 2). 

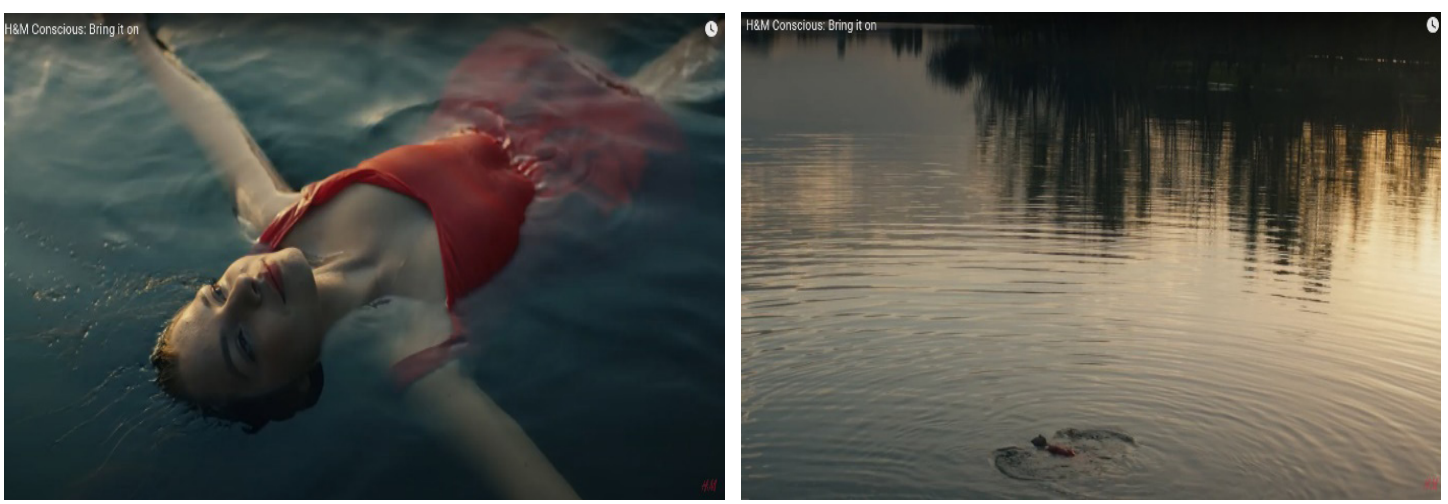

Şekil 3.

Tablo 2. Şekil 3 Analizi

\begin{tabular}{|l|l|l|l|}
\hline Gösterge & Gösteren & Gösterilen & Yan anlam \\
\hline İnsan & Kadın & $\begin{array}{l}\text { Suyun içinde } \\
\text { uzanan kadın }\end{array}$ & $\begin{array}{l}\text { Kadın kendini özgürce suyun içine bırakmıştır. Yüzündeki } \\
\text { tebessüm huzuru temsil etmektedir. Kadının yüzmediği, } \\
\text { sadece sırt üstü durduğu görülür, kendini suya teslim } \\
\text { etmiştir. Anı yaşamakta ve yaşadığı andan keyif almaktadır. } \\
\text { Yüzündeki ifade, keyifli olduğunu onaylamaktadır ve kadın } \\
\text { bulunduğu yerden gökyüzüne doğru bakmaktadır. }\end{array}$ \\
\hline Nesne & Elbise & $\begin{array}{l}\text { Kırmızı bir elbise } \\
\text { Elbise ile suya } \\
\text { giren kadın }\end{array}$ & $\begin{array}{l}\text { Suya elbise ile girmesi, insanın istediği anda istediğini yapmasına } \\
\text { işaret etmektedir. Kadın yüzmek için herhangi bir plan yapmamış, } \\
\text { yanına suya girmek için uygun bir kıyafet almamış ve üstündekiler } \\
\text { ile suya girmiştir. Anı yaşamak teması işlenmektedir. }\end{array}$ \\
\hline Renk & Kırmızı & Elbisenin rengi & $\begin{array}{l}\text { Kırmızı aşk, şehvet, cinsellik, tutku gibi anlamlar taşımaktadır. } \\
\text { Kırmızının iddialı ve dikkat çeken bir renk olduğu görüşü yaygındır. }\end{array}$ \\
\hline Doğa & Göl & Durgun bir göl & $\begin{array}{l}\text { Durgun, dalgası, hareketsiz bir su, dinginlik ve sakinlik } \\
\text { anlamları taşımaktadır. Su, saflık ve temizliğe işaret etmektedir. } \\
\text { Durgun su ise, huzuru temsil edebilir. Kadının duruşu ile suyun } \\
\text { durgunluğu uyumlu bir biçimde birbirini tamamlamaktadır. }\end{array}$ \\
\hline
\end{tabular}

Sonrasında, bir köpek ile bir insanın bir gömleği çekiştirdikleri görülür. Hamile bir kadın tişörtünü karnının üstüne çekiştirir, lekeli bir gömlek görülür ve en sonda da spor yapan kadının taytının yırtılma sesi duyulur. Dış ses ise şu sözleri söylemektedir; "Haydi getir, kaçık çorabını, lekeli tişörtünü, rengi atmış iç çamaşırını, tek çorabını, solmuş elbiseni. Hiç giymediğin o şeyi, bunu ve bunu ve onu.". Gönderme yapılan tüm kıyafetler, giysi toplama ve geri dönüşüm kampanyasında kullanılabilecek gözden çıkarılabilecek işlevini yitirmiş ürünlerdir. Bu kıyafetler ve çok daha fazlası geri dönüşüm için mağazalara getirilmeyi beklemektedir.

Bir sonraki sahnede kadının üstündeki elbise çamaşır ipinde asılıdır. Elbise özgürce rüzgarda hareket etmektedir -dans eder gibi- ancak elbise, yanında asılı olan diğer kıyafetlerden renk olarak oldukça farklıdır. Diğer kıyafetler genellikle mavi ve soluk renklere sahiptir ancak kırmızı elbise hemen göze çarpmaktadır (Şekil 4, Tablo 3). Hemen arkasından gelen sahnede ise genç bir çift, şehri yüksekten gören bir mekanda -bir çatıda- şakalaşmakta ve eğlenmektedir. Ellerinde bir çarşaf vardır. Çarşaf ilk olarak kafalarını örtecek şekilde durmakta ve çarşafın altında şakalaşmaktadırlar. Sonrasında ise erkek çarşafı kaptığı gibi koşarken kadın da onu takip etmektedir. Eğlendikleri ve mutlu oldukları görülmektedir (Şekil 5, Tablo 3). 

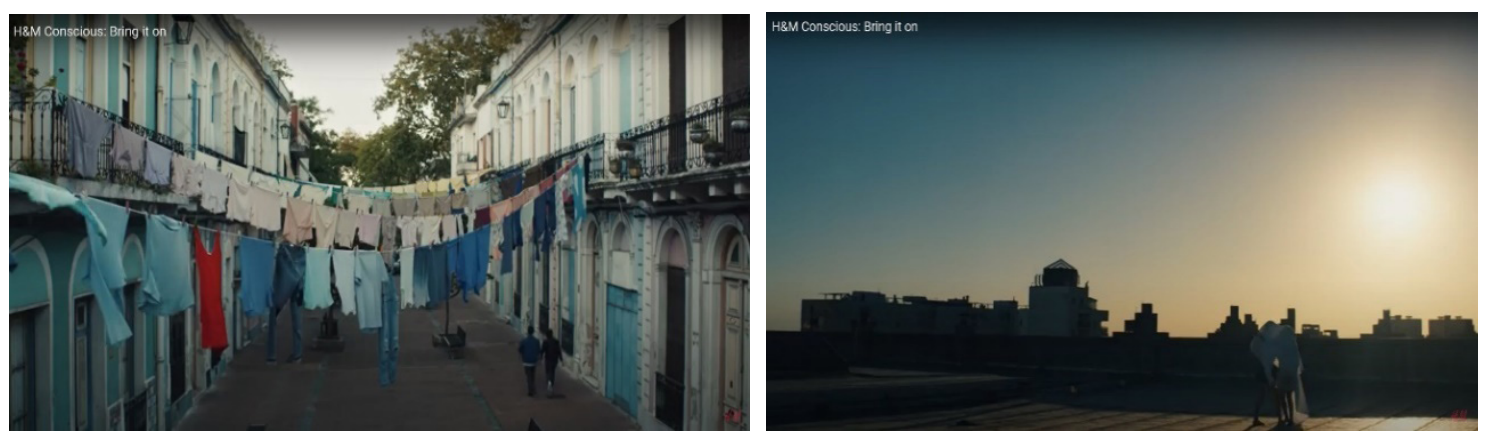

Şekil 4. ve Şekil 5.

Tablo 3. Şekil 4 ve Şekil 5 Analizi

\begin{tabular}{|l|l|l|l|}
\hline Gösterge & Gösteren & Gösterilen & Yan anlam \\
\hline Renk & Kırmızı & Kuruyan kırmızı elbise & $\begin{array}{l}\text { Rüzgarda uçuşan ve rengi diğer kıyafetlerden } \\
\text { farklı bir elbise, farklı olmak, özgür olmak, } \\
\text { kendini akışa bırakmak anlamlarını taşımaktadır. } \\
\text { Elbisenin renginin kırmızı olması, dikkat } \\
\text { çekiciliğe ve farklı olmaya işaret etmektedir. }\end{array}$ \\
\hline İnsan & Kadın/Erkek & Şakalaşan bir çift & $\begin{array}{l}\text { Eğlence, özgürlük, andan keyif almak ve birlikte } \\
\text { olmanın verdiği mutluluk temaları işlenmektedir. }\end{array}$ \\
\hline Nesne & Çarşaf & $\begin{array}{l}\text { Rüzgarda } \\
\text { uçuşan çarşaf }\end{array}$ & $\begin{array}{l}\text { Rüzgarın akışında özgürce uçuşan bir çarşaf } \\
\text { Özgürlük anlamına sahiptir. Çarşaf aynı zamanda } \\
\text { mahremiyeti de sembolize etmektedir. }\end{array}$ \\
\hline Doğa & Gün batımı & Güneşin batması & $\begin{array}{l}\text { Ömrü dolmuş kıyafetler gibi günde sona ermiştir. } \\
\text { Kampanyanın temel amacı da metaforik olarak } \\
\text { kıyafetlerin yeniden doğmasıyla ilgilidir. }\end{array}$ \\
\hline Mekan & Çatı & $\begin{array}{l}\text { Kenti/şehri yüksekten } \\
\text { gören bir yer }\end{array}$ & $\begin{array}{l}\text { Yükseklik, her şeye hakim olmak, şehre yukarıdan } \\
\text { bakmak, özgür ve bağımsı olmak ile ilgilidir. }\end{array}$ \\
\hline
\end{tabular}

Göstergeler incelenirken dikkat çeken bir unsur mekanların ışık durumuna ilişkindir. Şekil 1, 2, 3 ve 5 'te de görülebileceği gibi loș bir ortam veya gün batımı teması ișlemiștir. Şekil 1'de partinin olduğu mekan oldukça karanlıktır, Şekil 3'te suyun içindeki kadını uzaktan gördügümüz sahnede gün batımı olduğu anlaşılmaktadır. Şekil 5'te çatıda koşan çiftin karşısından güneş batmaya başlamıştır. Tüm bu loş ve hafif karanlık görseller, eski klyafetlere gönderme niteliğindedir. Geri dönüşüme uygun olarak tüm bu kıyafetler, sanki bir gün batımı gibi yitip gitmekte ve yeni ürünler olma yolunda dönüştürülmeyi beklemektedir. Zaman gelmiştir, bir gün bitmekte ve yeni bir gün yakındadır. Eski kıyafetlerin de metaforik olarak bu dönüșümde sıraları gelmiştir.

Filmin ilerleyen sahnelerinde yine geri dönüşüme uygun kıyafetler tasvir edilmektedir. İzleyicinin zihninde nelerin geri dönüşüme uygun olduğu fikri işlendikten sonra, arada bir geçiş sahnesinin olduğu görülür. Bu geçiş sahnesinde kolları kıyafet dolu bir kadın, bir yere doğru yürümektedir. Bu sahnede dış sesin "Eskileri getir, biz hallederiz." dediği duyulmaktadır. Kadının kolunda taşıdığı kıyafetlerin, geri dönüştürülecek kıyafetler olduğu anlaşılmaktadır (Şekil 6, Tablo 4). Bu görüntünün hemen arkasından ise bir kadın, ağaçlar arasında görülür. Kadın, bir ağaca dokunmaktadır ve dış ses, "Evet, Haydi bu vicdan azabına son verelim." demektedir (Şekil 7, Tablo 4). 

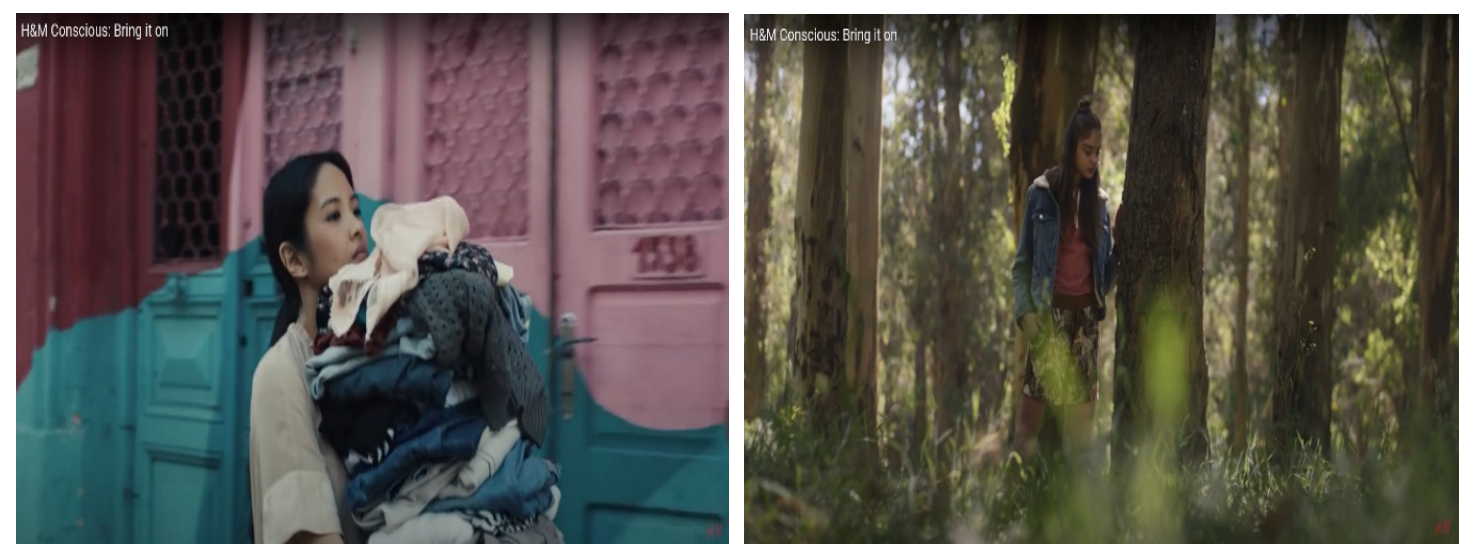

Şekil 6. ve Şekil 7.

Tablo 4. Sekil 6 ve Şekil 7 Analizi

\begin{tabular}{|l|l|l|l|}
\hline Gösterge & Gösteren & Gösterilen & Yan anlam \\
\hline Nesne & Kıyafet & $\begin{array}{l}\text { Kolları kıyafet } \\
\text { dolu bir kadın }\end{array}$ & $\begin{array}{l}\text { Özensiz bir biçimde üst üste toplanmış kıyafetler } \\
\text { gözden çıarılmış kıyafetleri sembolize etmektedir. } \\
\text { Bunlar, geri dönüşüme gidecek kıyafetlerdir. }\end{array}$ \\
\hline Doğa & Ağaç/orman & $\begin{array}{l}\text { Ağacın yanında } \\
\text { duran bir kadın }\end{array}$ & $\begin{array}{l}\text { Eski kıyafetlerin geri dönüşümü doğayı } \\
\text { kurtarmaktadır. Kadın ise tüketici olarak } \\
\text { sorumluluğunu yerine getirerek huzur bulmuş, } \\
\text { ait olduğu yere doğaya dönmüştür. Dış sesin } \\
\text { de belirttiği gibi "vicdan azabı" sona ermiştir. }\end{array}$ \\
\hline
\end{tabular}

Filmin devam eden sahneleri geri dönüşüme giren kıyafetlerin yolculuğunu izleyiciye göstermektedir (Şekil 8). Bu sahnelerde dış sesin "Yükleyelim, bırakalım, fırlatalım, düzenleyelim, sıkalım, yığalım, yollayalım da başkası giyin, mesela o ya da o." dediği duyulur. Sonraki sahnede bir caddenin tam ortasında duran ve üzeri tamamen pullu bir elbise giymiş bir kadın, bunu takip eden sahnede ise aynı noktada, aynı elbiseyi giyen bir erkek görülür. Aynı mekan ve aynı elbise ile çekilen ve peş peşe gösterilen bu iki sahne ve elbiseyi hem bir kadının hem de bir erkeğin giymiș olması, markanın özgürlüklere yaptığı vurguya işarettir. Filmde pek çok farklı sembol ile işlenmiş olan özgürlük ve tercihleri özgürce yaşama anlayışı, bu iki görsel ile de pekiştirilmiştir.
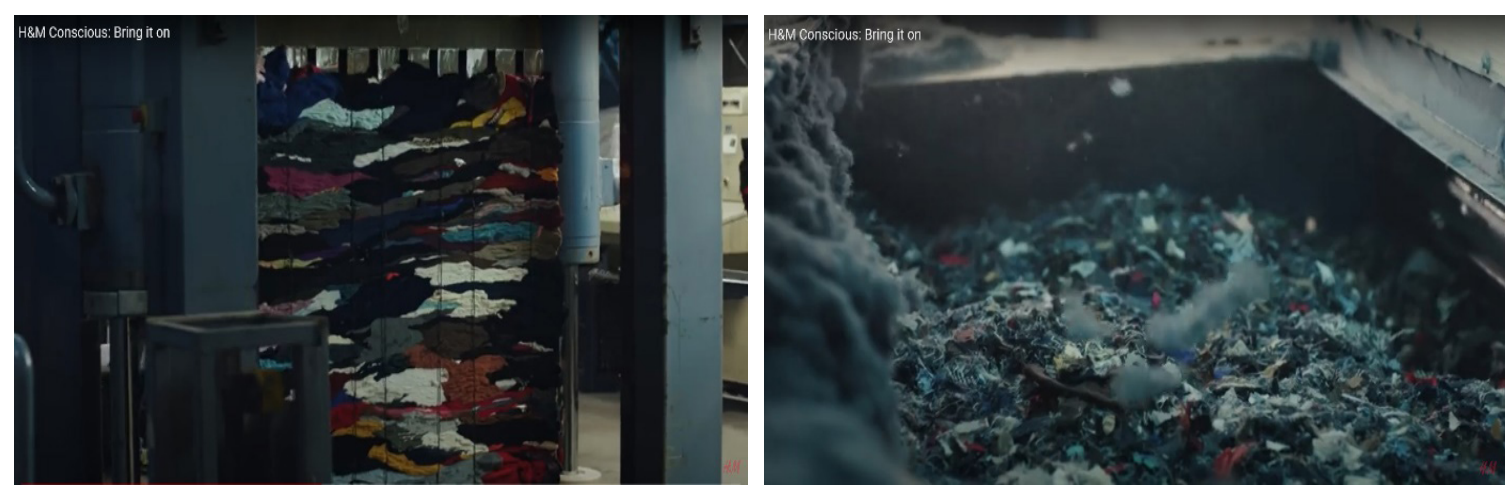

Şekil 8.

Geri dönüşüm sürecinin anlatıldığı sahnelerin arasında yer alan insan görselleri de dikkat çekmektedir. İşlemlerin anlatıldığı sahnelerin arasına serpiştirilmiş bu sahneler, filmin başından beri işlenen insan profilleri ile benzerlik göstermektedir. Bu sahnelerde insanların eğlendikleri görülmektedir.

Tüm bu dönüşüm işlemlerinden sonra karşımıza çıkan bir sahne, yine geri dönüşümün doğayla olan ilişkisine işaret etmektedir. Kuş sesleri eșliğinde bir kadın yeșil bir arazide 
görülür ve kadının üzerinde çiçek desenli bir etek vardır. Ancak bu sahne, diğer sahnelere göre çok daha aydınlıktır. Sahnenin aydınlık olmasının sembolik olarak bir anlamı olduğu düşünülmektedir. Eski kıyafetlerin olduğu sahnelerde daha loş ortamlar kullanılırken karanlık, kıyafetlerin eski ve gözden çıkarılmış olmasına işarettir. Ancak geri dönüşüme temas eden ve doğayla insanı bir araya getiren sahnelerin -Şekil 7'de de ormanda görünen kadının arkasından da güneşin parladığı dikkat çekmiştir- daha aydınlık olduğu, gündüz ve havanın güneşli olduğu görülmektedir. Aydınlık, geri dönüşüm ile doğayı koruma ilişkisine işaret etmektedir ve bu görseli gördüğümüz anda dış ses "Sen sadece getir" cümlesini söylemektedir (Şekil 9, Tablo 5).

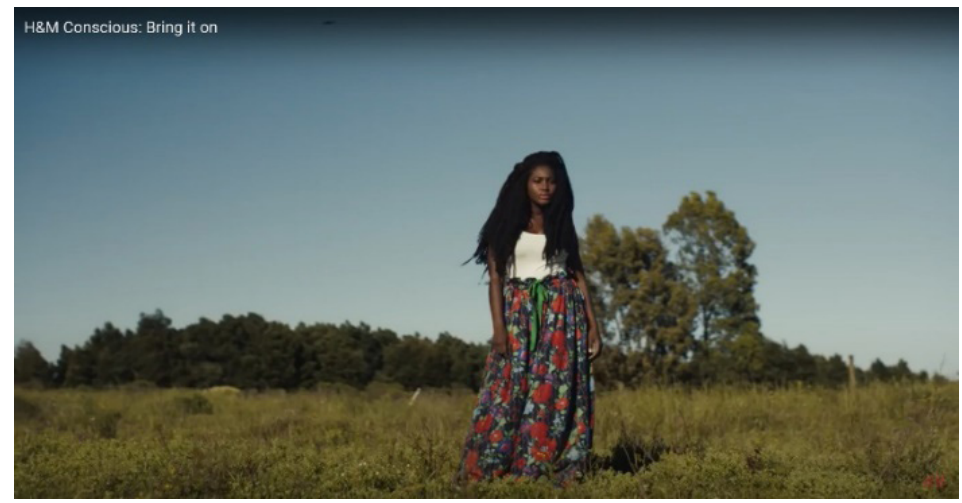

Şekil 9.

Tablo 5. Şekil 9 Analizi

\begin{tabular}{|l|l|l|l|}
\hline Gösterge & Gösteren & Gösterilen & Yan anlam \\
\hline Nesne & Kıyafet (etek) & Çiçek desenli etek & $\begin{array}{l}\text { Çiçek deseni eteği doğanın bir parçası } \\
\text { olarak konumlandırmaktadır. Geri dönüşum } \\
\text { anlayışı doğayı korumakla ilgilidir ve geri } \\
\text { dönüşüm ürünleri doğayı korumakla birlikte } \\
\text { doğadan ilham alan desenlere sahiptir. }\end{array}$ \\
\hline Doğa & Ağaç/çimen & $\begin{array}{l}\text { Çimenlerin ortasında } \\
\text { duran bir kadın }\end{array}$ & $\begin{array}{l}\text { Doğayla iç içe olmak, doğayı sevmek, } \\
\text { korumak, onun bir parçası olmak sembolize } \\
\text { edilmiştir. Geri dönüşüme destek vermek, aynı } \\
\text { zamanda çevresel duyarlılıkla da ilgilidir. }\end{array}$ \\
\hline
\end{tabular}

İlerleyen sahnelerde insanların kullanmadıkları kıyafetlerini torbalara doldurdukları görülür. Bir arkadaş grubunun klyafet dolu torbalarla akşam saatlerinde caddede yürüdükleri sahneden sonra, klyafet toplama kutusu gösterilir ve klyafetlerin o kutuya atılma sahnesi izleyiciye sunulur. Yolda yürüyen arkadaş grubunun yine çok neşeli olduğu dikkat çekmektedir. Dış sesten ise "İşe yaramazlar, uymayanları, gereksizleri... Gerekeni yaparız. Ama asla israf etmeyiz” cümleleri duyulur (Şekil 10).
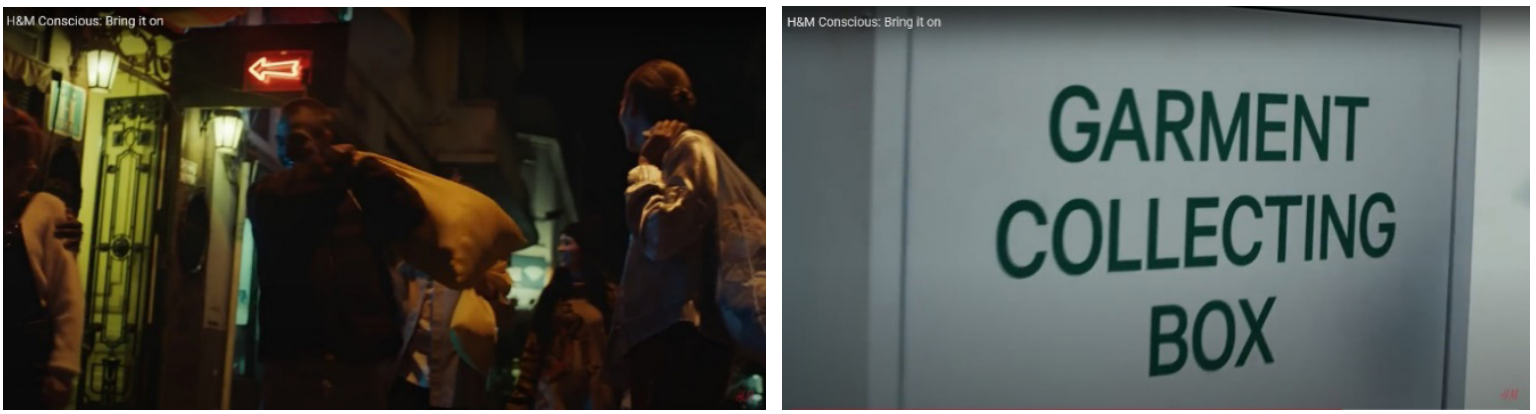

Şekil 10.

Filmin en son sahneleri (Şekil 11) filmin ana fikri ortaya koyar niteliktedir. Şekil 11'deki görüntülerin ilkinde "İstenmeyen klyafetlerinizi herhangi bir mağazamıza getirin", 
ikincisinde ise "Yeni bir hayata başlamalarını sağlayalım" ifadeleri yer almaktadır. Yeni kıyafetler umudun ve mutluluğun bir parçası olmaları için tüketiciyle buluşturulmaktadır (Tablo 6). Kapanışta yer alan cümleler ise filmin özetidir; "Birlikte döngüyü tamamlayalım. Giysilerinizi mümkün olan en uzun süre sevin ve koruyun. Yeni bir hayata başlamaları için H\&M'e getirin. [...]"
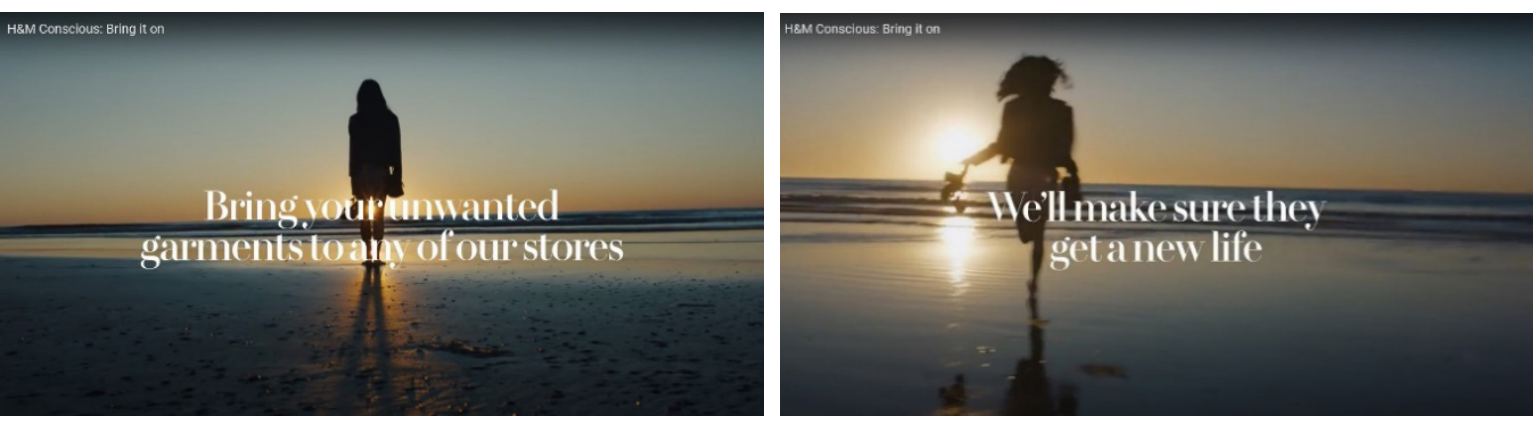

Şekil 11.

Tablo 6. Şekil 11 Analizi

\begin{tabular}{|l|l|l|l|}
\hline Gösterge & Gösteren & Gösterilen & Yan anlam \\
\hline Doğa & Gün batımı & Güneşin batışı & $\begin{array}{l}\text { Güneşin batışı, hem filmin son sahneleri olması, hem } \\
\text { de geri dönüşüm tamamlanması açısından önemli } \\
\text { bir göstergedir. Döngünün sona ermesi, yeni bir güne } \\
\text { hazırlık anlamları aktarımaktadır. Güneşin batışı aynı } \\
\text { zamanda, filmin bitmesine de işaret etmektedir. }\end{array}$ \\
\hline Doğa & $\begin{array}{l}\text { Deniz (okyanus) } \\
\text { ve sahil }\end{array}$ & Deniz ve sahil & $\begin{array}{l}\text { Özgürlük, sonsuzluk, yaşamın kaynağı olması } \\
\text { açısından suyun önemine işaret edilmektedir. } \\
\text { Geri dönüşüm sürecinde su da korunması } \\
\text { gereken önemli bir doğal kaynaktır. }\end{array}$ \\
\hline
\end{tabular}

H\&M "Let's change. For tomorrow."2 (2020)

H\&M'in YouTube hesabından erișilen video, 28 Mayıs 2020 tarihinde yayınlanmıștır. Filmde bir grup kadın keyifli bir biçimde şehirde ve doğada dolaşırken görülmekte ve dış ses, H\&M'in geri dönüşüm politikalarına dair bilgiler aktarmaktadır. Otuz saniye süren video, geri dönüşüm materyallerinden üretilen elbiselerin de sergilendiği bir reklam niteliği taşımaktadır.

Filmin ilk sahnesinde bir grup kadının șehrin yüksek bir noktasından şehri seyrettikleri görülmektedir. Havanın aydınlık oluşundan günün erken saatleri olduğu anlaşılmaktadır (Şekil 12, Tablo 7). Bu sahnede dış sesin “Dünya değiști. Bugün yaptıklarımız yarınımızı tanımlayacak" ifadelerini kullanmaktadır. Bu ifade, bugünkü eylemlerimizin geleceğe olan etkilerine işaret edilmektedir.
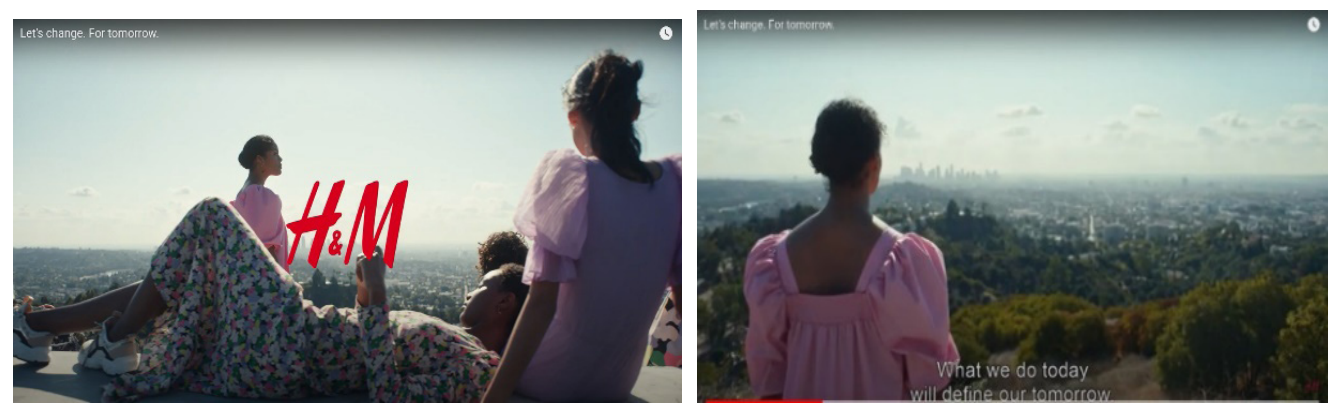

Şekil 12. 
Tablo 7. Sekil 12 Analizi

\begin{tabular}{|l|l|l|l|}
\hline Gösterge & Gösteren & Gösterilen & Yan anlam \\
\hline İnsan & Kadın & Kadın arkadaş grubu & $\begin{array}{l}\text { Kadınların grup halinde olmaları, ortak } \\
\text { hareket etmeyi, ortak bir amaç uğruna bir } \\
\text { araya gelmeyi sembolize etmektedir. }\end{array}$ \\
\hline Mekan & Şehir/kent & $\begin{array}{l}\text { Kuş bakışı şehir } \\
\text { görüntüsü }\end{array}$ & $\begin{array}{l}\text { Şehir, sanayileşmenin sembolüdür. Kadınların şehre } \\
\text { uzaktan bakış, çevre dostu ve geri dönüşümü } \\
\text { destekleyen politikaları desteklemektedir. Bu } \\
\text { sahne, şehrin sembolize ettiklerinin dışında durmak, } \\
\text { karşısında olmak gibi okunabilir. Şehir ve doğa, } \\
\text { karşıt iki unsur gibi konumlandırılmıştır. Şehrin } \\
\text { üstünde sis ve pus perdesi bulunmaktadır. Sis ve } \\
\text { puslu görüntü, kasvetli, kirli bir imaj çizmektedir. }\end{array}$ \\
\hline Doğa & Ağaç/orman & $\begin{array}{l}\text { Orman-ağaç } \\
\text { görüntüsü }\end{array}$ & $\begin{array}{l}\text { Şehrin bittiği yerde belirgin bir yeşillik örtüsü } \\
\text { görülmektedir ve kadınlar da arkaları yeşillik } \\
\text { bir yerde durmaktadırlar. Doğa görselleri, } \\
\text { çevresel duyarlıı̆ı temsil etmektedir. }\end{array}$ \\
\hline Yazı & Harfler & Markanın logosu & $\begin{array}{l}\text { Tanıtım filmine atılan imzadır, filmin } \\
\text { kime ait olduğunu gösterir. }\end{array}$ \\
\hline
\end{tabular}

Filmin devamında kadınların, kararlı adımlarla șehrin kalabalık sokaklarından geçtikleri ve sonrasında yine ormanlık bir araziye geldikleri görülür. Bu sırada dış sesin "Malzemeleri nasıl seçtiğimizi ve ürünlerimizi nasıl yaptığımızı değiștirmeye devam edeceğiz" dediği duyulur. Şehrin kalabalık caddelerinin, trafiğin ve araçların sebep olduğu yoğunluk ve kaos karşısında kadınların soft renkteki elbiseler ile aynı karede görünümü bir karşıtlık gibi sunulmuştur. Buna göre kadınlar elbiseleriyle doğal ve naif bir görünüm sergilerken șehir, kaosu, karmaşayı, sanayileşmeyi ve hızlı yaşamı temsil etmektedir. Kadınların üstlerindeki elbiseler ise ayrıca dikkat çekicidir. Elbiseler, markanın geri dönüşüm koleksiyonunun parçalarıdır ve elbiselerin model ile desenleri dikkat çekicidir (Şekil 13, Tablo 8).
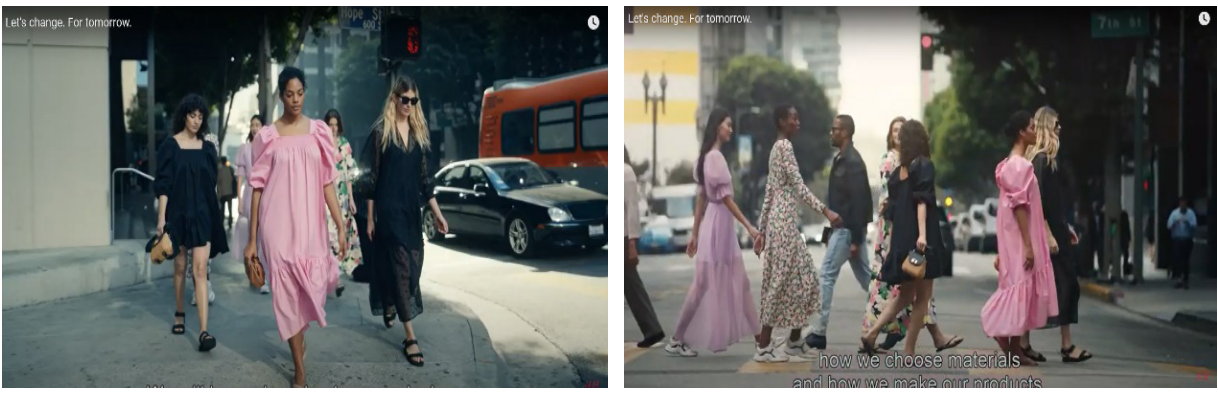

Sekil 13.

Tablo 8. Sekil 13 analizi

\begin{tabular}{|l|l|l|l|}
\hline Gösterge & Gösteren & Gösterilen & Yan anlam \\
\hline Mekan & Şehir/kent & $\begin{array}{l}\text { Kent yaşamı, trafik, } \\
\text { trafik ışıkları, araçlar }\end{array}$ & $\begin{array}{l}\text { Geri dönüşüm ve çevreci anlayışın temsilen } \\
\text { kadınlar, şehir ile bir araya gelmekte, } \\
\text { harmanlanmaktadır. Kadınlar şehrin işlek } \\
\text { caddelerinde dolaşıp sanki temsil ettikleri bu } \\
\text { anlayışı şehrin geneline yaymaktadırlar. }\end{array}$ \\
\hline Nesne & Kıyafet/elbise & Elbise giyen kadınlar & $\begin{array}{l}\text { Kadınları hepsi elbise giymektedir, markanın geri } \\
\text { dönüşüm koleksiyonunda pantolon gibi ürünler } \\
\text { olmasına rağmen elbise tercih edilmiştir. Elbise } \\
\text { feminen bir kıyafettir. Ayrıca filmin yayınlandığı } \\
\text { tarih dikkate alındığında, yaz sezonu olmasından } \\
\text { dolayı elbiseye ağılılık verildiği düşünülmektedir. }\end{array}$ \\
\hline Renk & Elbise renkleri & $\begin{array}{l}\text { Soft renklerde ve } \\
\text { genellikle çiçek } \\
\text { desenli elbiseler }\end{array}$ & $\begin{array}{l}\text { Elbiselerde kullanılan renkler ve desenler, } \\
\text { doğayla uyumludur. Soft renklerin tercih } \\
\text { edildiği ürünler, doğallığın temsilidir. }\end{array}$ \\
\hline
\end{tabular}


Bir sonraki sahnede kadınların bir parka-ağaçlık bir alana geldikleri görülür ve kadınlar yürümeye devam etmektedir. Bu sahnelerin başladığı anda "Kullanımı, yeniden kullanıma ve geri dönüşüme dönüştürüyoruz. Zaten malzemelerimizin yarısından fazlası geri dönüştürülmüş organik veya sürdürülebilir kaynaklıdır. 2030'a kadar ise bu yüzde 100 olacaktır" ifadeleri duyulmaktadır. Dış sesin verdiği bilgi ile kadınların şehirden ayrılarak ağaçlık araziye gelmeleri arasında bir paralellik vardır. Kadınlar da şehrin kalabalığından uzaklaşıp yeniden doğaya dönmüşlerdir. Aynı markanın kıyafetleri geri dönüştürerek yeniden kullanmayı amaçladı̆̆ı gibi.

Filmin devam eden sahnelerinde ağaçlar arasından güneş ışığı parlamakta ve kadınların yüzünde neşeli ve mutlu bir ifade bulunmaktadır. Kadınlar ağaçlık arazide dolaşıp, birbirleriyle keyifli zaman geçirmektedirler. Son sahnelerde filmin başladığı yere geri dönen kadınlar, umut dolu ifadelerle tekrar uzaktan şehre bakarlar ve bu sırada güneş batmaktadır. Filmin son sahnesi, güneş batarken kadınların hepsinin bulundukları yerden kalkıp uzaklaşmaya başladıkları görüntüdür. Dış ses filmi, hem markanın geri dönüşüm ürünlere ilișkin hedefini yansıtan, hem filmin ismi hem de sloganı olan "Hadi değiștirelim. Yarın için” sözleriyle bitirir (Şekil 14, Tablo 9).

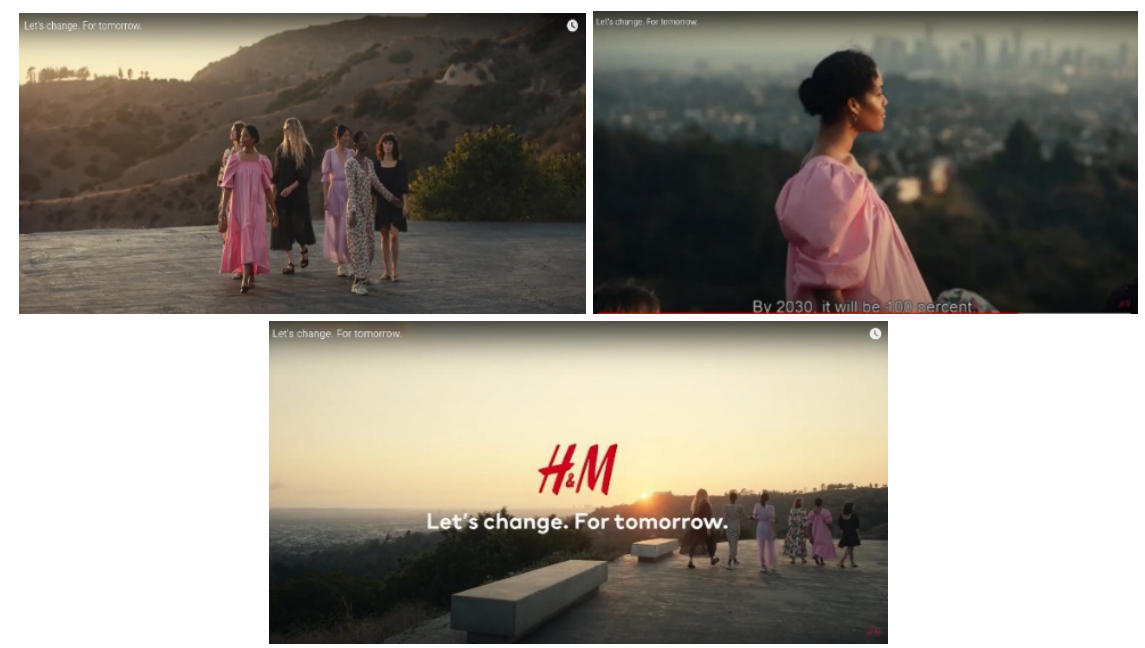

Şekil 14.

Tablo 9. Şekil 14 Analizi

\begin{tabular}{|l|l|l|l|}
\hline Gösterge & Gösteren & Gösterilen & Yan anlam \\
\hline Doğa & Güneşin batışı & $\begin{array}{l}\text { Dağların } \\
\text { arkasından } \\
\text { güneşin batışı }\end{array}$ & $\begin{array}{l}\text { Güneşin batışı bir günlük döngünün bitişidir. Aynı } \\
\text { geri dönüşüme giren ve yeni bir ürün olarak doğan } \\
\text { kıyafetler gibi, her şeyin bir döngüsü bulunmaktadır. }\end{array}$ \\
\hline İnsan & Kadın & $\begin{array}{l}\text { Tebessüm ederek gün batımına ve şehre bakan } \\
\text { kadınlar umudu temsil etmektedir. Filmin ilk } \\
\text { sahnesinde de kadınların aynı yerden şehre } \\
\text { baktıkları görülmüştür. Açılış sahnesinde havanın } \\
\text { aydınlık olması günün erken saatleri olduğunu } \\
\text { düşündürmekte, kapanış sahnesinde ise güneşin } \\
\text { batması, hem filmin bitişini hem de kıyafetlerin geri } \\
\text { dönüşüm döngüsünü sembolize etmektedir. }\end{array}$ \\
\hline İnsan & Kadıan kadınlar & $\begin{array}{l}\text { Kadınlar, görevlerini başarıyla tamamlamış edasıyla, } \\
\text { bulundukları bölgeden neşeyle ayrılırlar. }\end{array}$ \\
\hline
\end{tabular}

\section{Sonuç ve Değerlendirme}

Son yıllarda çevresel sorunlara ve doğal kaynakların tükenmesine yönelik artan bilinç, hem tüketiciler hem de markalar açısından önemli sonuçlara yol açmıştır. Moda sektörü sosyal sorumluluk uygulamalarını, çevre ve doğal kaynaklar üzerine olan olumsuz 
etkilerinin de bir sonucu olarak, giderek daha fazla çevresel konulara doğru kaydırmıștır. Çalışma kapsamında moda sektörünün ve özellikle de hızlı modanın aktörlerinden biri olan H\&M markasının, kurumsal sosyal sorumluluk çalıșması olan "Kıyafet Toplama Programı-Modada Geri Dönüşüm” projesi kapsamında iki filmi, göstergebilim yöntemiyle incelenmiștir. $\mathrm{Bu}$ filmlerin markanın sosyal sorumluluk anlayışını anlamak, geri dönüşüm ve kıyafet toplama projesini kamuoyuna nasıl aktardığını görmek ve sosyal sorumluluk anlayışını hangi kodlar üzerinden inşa ettiğini açıklamak açısından önemli olduğu düşünülmektedir.

Araştırmanın amacı ve soru cümleleri kapsamında analiz edilen filmlerden elde edilen bulgular değerlendirildiğinde şu sonuçlara varmak mümkündür. Filmlerde genel olarak özgürlük, eğlence, mutluluk, huzur, kendine güven, farklı olmak, umut, anı yaşamak, özgüven gibi temalar işlenmiştir. Kullanılan bu göstergeler ile markanın ürünlerini kullanan tüketicilere bu nitelikleri vaat ettiği söylenebilir. Filmlerde yer verilen göstergeler ve kullanılan temaların, aynı zamanda marka konumlandırması ile ilgili olduğunu da söylemek mümkündür. Genel olarak genç bir tüketici kitlesine sahip olan ve genellikle gençleri hedefleyen markanın mesajlarını hedef kitlesi doğrultusunda oluşturduğu düşünülmektedir.

Öte yandan geri dönüşümün önemine dikkat çekmek, geri dönüşüm sürecini ve geri dönüşümün çevresel etkilerini izleyiciye göstermek, tüketicilerin de bu sürecin bir parçası olmasını sağlamak amacıyla filmlerde, ağaç, orman, çimen, göl ve deniz gibi doğa görsellerinin sıkça kullanıldığı görülmüştür. Kullanılan bu göstergeler ile proje ile amaçlanan olumlu çevresel etkiler resmedilmeye çalışılmıştır. Aynı zamanda filmlerde kullanılan kıyafetler dikkat çekmiştir. Kıyafetlerin renk ve desenleri de doğaya ve çevreye ilişkin yapılan göndermeleri desteklemiştir. Özellikle ikinci filmde kullanılan kıyafetlerin markanın geri dönüşüm koleksiyonunun parçaları olduğu görülmüștür. Böylece hem ürünlerin reklamı yapılmış, hem de konuyla ilgili farkındalık yaratılmaya çalıșılmıştır. Kıyafetlerde genellikle soft renkler ve çiçek gibi desenli kumaşlar kullanılarak doğayla görsel bir bütünlük yaratılmaya çalışılmıştır.

Her iki filmde de dikkat çeken bir diğer unsur ise, insanların genellikle arkadaş grupları ya da çiftler olarak gösterilmesidir. Filmlerde resmedilen tüm insanların, mutlu oldukları ve eğlendikleri görülmüștür. Son olarak ise filmlerde, genellikle kadınlar ön planda tutulmuştur. Özellikle incelenen ikinci filmde tüm karakterlerin kadın olması dikkat çekmiştir. Kadınlara atfedilen bu rolün ise, moda ile kadın arasındaki ilişkiden kaynaklandığı düşünülmektedir. Her ne kadar moda tüm insanlar için olsa da, kadınların moda ile kurdukları ilişkinin çok daha özel olduğu yaygın bir kabuldür.

Çalışmanın amacı, elde edilen bulgular ile sosyal sorumluluk, sürdürülebilirlik ve geri dönüşüm arasındaki ilişki bağlamında çalışma sonucunda şunları söylemek mümkündür. Deren van het Hof ve Hoştut'un (2020, s. 27) belirttikleri gibi, "bazı şirketler için sosyal sorumluluk kuruluş nedeni"dir. İncelenen tanıtım filmleri ile markanın yürütmüş olduğu çalışmalar bütün olarak değerlendirildiğinde, geri dönüşüm ve sürdürülebilirlik anlayışının H\&M markasının varlığının ve sosyal sorumluluk anlayışının en temel parçalarından biri olduğu net bir biçimde görülebilir. Markanın, Birleşmiş Milletler Küresel İlkeler Sözleşmesi'nin üyesi olması da, bu açıdan değerlendirilebilir. Her ne kadar marka, tüketimin devamlılığına dayanan hızlı modanın temsilcilerinden biri olsa da, sahip olduğu sorumluluk anlayışının hızlı moda endüstrisinde de uygulanabilir olduğunu göstermektedir. Aynı zamanda projenin, herhangi bir zaman dilimi ile sınırlandırılmamış 
olması ve proje kapsamında uzun soluklu hedeflerin belirlenmesi, sürdürülebilirlik ve sosyal sorumluluk anlayıșının markanın yönetsel yapısına nasıl egemen olduğunun da bir göstergesidir.

Öte yandan her çalışma belirli bir sınırlılık içerdiğinden, araştırma kapsamında markanın yalnızca iki tanıtım filmi incelenebilmiş olup markanın geri dönüşüm anlayışını yansıtan daha pek çok tanıtım/reklam filmi olduğu da bilinmektedir. Örneğin, 2020 yılında yayınlanmış olan "Let's change. In every detail", "Bring on the future", "H\&M Conscious Exclusive A/W20"3 gibi pek çok tanıtım/reklam filmi bu kapsamda incelenebilir. Tüm bu tanıtım filmleri, taşıdığı mesajlar itibariyle sorumluluk bilincini kamuoyuna aktarmanın bir aracı olarak da görülebilir. Kampanya kapsamında yürütülen "klyafet toplama" çalışmaları da, kamuoyunu bir paydaş olarak sosyal sorumluluk sürecinin parçası haline getirme çabası olarak okunabilir.

İncelenmiş olan tanıtım filmlerinde yer alan ifadeler genel olarak değerlendirildiğinde ise, "gelecek" ve "yarın" vurgusunun yoğun bir biçimde işlendiği dikkat çekmiştir. İçinde bulunduğumuz çağın değiştiği ve değişime ayak uydurma zorunluluğu, farklı biçimlerde izleyiciye aktarılmaktadır. Pek çok insan için "eski" ya da "kullanılmaz" olan ürünlerin, israf etmeden yaşam döngüsüne nasıl dahil edilebileceğinin mesajı farklı ifadelerle kodlanırken, filmlerde kullanılan tüm göstergeler geri dönüşümün doğaya, çevreye ve sürdürülebilir modaya olan katkılarını yansıtmaktadır. Bu mesajlar, sürdürülebilirlik anlayışının göstergeleri olarak değerlendirilebilirken aynı zamanda markanın kendi misyonunu da tanımlamaktadır.

Sonuç olarak, hızlı moda sektörüne ait önemli markaların çevresel hassasiyetlerinin giderek arttığı ve bu hassasiyetlerini kurumsal sosyal sorumluluk çalışmalarıyla destekledikleri görülmüştür. H\&M, geri dönüşüm kampanyası ile ortaya koyduğu bu duyarlılığa, tüketicilerini de paydaş olarak dahil etmiş ve hem tüketiciler açısından hem de kurum açısından "kazan-kazan" anlayışı gündeme gelmiştir. Geri dönüşüme getirilen her bir poşet başına bir sonraki alıșverişte kullanılabilecek hediye çeki verilmesi uygulaması ile hem tanıtım sağlanmış hem de kamuoyunda sosyal sorumluluk bilincine ilişkin olumlu bir algı yaratılması mümkün olmuştur.

\section{Notlar}

1"Bring it/Bring it on" "Haydi getir/Bırakın gelsin", "Getir onu” olarak Türkçeleştirilebilir. Araştırmanın yapıldığı tarih itibariyle (19.07.2020) izlenme sayısı, 591.767'dir.

2"Let’s change. For tomorrow”, "Hadi değiştirelim. Yarın için." olarak tercüme edilebilir. Araştırmanın yapıldığı tarih itibariyle (28.07.2020) görüntülenme sayısı, 67.531'dir. ${ }^{3}$ Bahsedilen tüm tanıtım/reklam filmlerine ve çok daha fazlasına, H\&M'in kurumsal YouTube hesabından (https://www.
youtube.com/c/HM/featured) erişmek mümkündür.

\section{Kaynakça}

Aktulum, K. (2019). Metinsel türsellik ve moda metinlerarasıllk - giysilerarasılık üstgiysisellik. Yeni Türk Edebiyatı Araştırmaları, 11(21), 1-37.

Atılgan, T., Kanat, S., \& Illeez, A. (2011). The environmental effects of corporate social responsibility development of enterprises. Akdeniz Sanat, 4(8), 73-79.

Barbarosoğlu, F. (2015). Moda ve zihniyet. İstanbul: İz Yayıncılık.

Barnard, M. (2002). Fashion as communication. London\&New York: Routledge.

Barthes, R. (1986). Elements of semiology. New York: Hill and Wang. 
Barthes, R. (1990). The fashion system. Berkeley: University of California Press.

Batı, U. (2007). Reklamların göstergebilimi: 'Bir göstergeler sistemi olarak reklamları okumak'. Uluslararası İnsan Bilimleri Dergisi, 4(1), 1-28.

Bauer, M., \& Gaskell, G. (Dü). (2000). Qualitative researching with text, image and sound: A practical handbook. London: Sage Publications.

Bayraktaroğlu, G., Tanyeri, M., \& İlter, B. (2009). Kurumsal sosyal sorumluluk: Pazarlamada yeni bir paradigmaya doğru. İstanbul: Literatür Yayıncılık.

Binet, F., Coste-Manière, I., Decombes, C., Grasselli, Y., Ouedermi, D., \& Ramchandani, M. (2019). Fast fashion and sustainable consumption. S. S. Muthu (Dü.) içinde, Fast Fashion, Fashion Brands and Sustainable Consumption (s. 19-35). Springer.

Björklund, M. (2010). Benchmarking tool for improved corporate social responsibility in purchasing. Benchmarking: An International Journal, 17(3), 340-362.

Buzzo, A., \& Abreu, M. J. (2019). Fast fashion, fashion brands \& sustainable consumption. S. S. Muthu (Dü.) içinde, Fast Fashion, Fashion Brands and Sustainable Consumption (s. 1-17). Springer.

Can, Ö., \& Ayvaz, K. M. (2017). Tekstil ve modada sürdürülebilirlik. Akademia Sosyal Bilimler Dergisi, 3(1), 110-119.

Carroll, A. (1979). A three-dimensional conceptual model of corporate performanc. The Academy of Management Review, 4(4), 497-505.

Chandler, D. (2007). Semiotics: The basics. London\&New York: Routledge.

Çeliksap, S. (2015). Giyim ve modanın kısa öyküsü. Aydın Sanat, 1(1), 57-63.

Danesi, M. (2002). Understanding media semiotics. London: Arnold.

Deren van het Hof, S., \& Çabuk, D. (2011). Kurumsal sosyal sorumluluk. M. Işık, \& M. Akdağ içinde, Dünden Bugüne Halkla İlişkiler (s. 49-61). Ankara: Eğitim Akademi Yayınları.

Deren van het Hof, S., \& Hoştut, S. (2020). Kurumsal sosyal sorumluluk kavramlar uygulama ve örnekler. Ankara: Nobel.

Fiske, J. (2003). İletişim çalışmalarına giriş. (S. İrvan, Çev.) Ankara: Bilim ve Sanat.

Gençtürk-Hızal, G. (2003). Bir iletişim biçimi olarak moda: "Modus”un sınırları. İletişim: Araştırmaları, 1(1), 65-86.

Global Compact Türkiye. (2020a). https://www.globalcompactturkiye.org/ adresinden alındı

Global Compact Türkiye. (2020b). https://www.globalcompactturkiye.org/10-ilke/ adresinden alındı

Göksel, N., \& Yanmaz, K. (2011). Modası geçmiş giysilerin yeniden kullanımına yönelik bir araştırma. Akdeniz Sanat, 4(8), 34-38.

Gürcüm, B. H., \& Yüksel, C. (2011). Moda sektörünü “yavaşlatan” eğilim: Eko moda ve moda'da sürdürülebilirlik. Akdeniz Sanat, 4(8), 48-51.

Gürel Boran, T. (2016). Türkiye'den uygulama örnekleriyle kurumsal sosyal sorumluluk. İstanbul: Beta. 
H\&M. (2017). https://www.youtube.com/watch?v=7i4JSzB8VlU\&feature=youtu.be adresinden alındı

H\&M. (2017a). https://hmgroup.com/media/news/general-2017/hm-bring-itcampaign.html adresinden alındı

H\&M. (2017b). https://about.hm.com/content/dam/hmgroup/groupsite/documents/ masterlanguage/CSR/reports/2017\%20Sustainability\%20report/HM_group_ SustainabilityReport_2017_FullReport.pdf adresinden alındı

H\&M. (2020). https://www.youtube.com/watch?v=DR2pFTdxZq8 adresinden alındı

H\&M. (2020a). https://www2.hm.com/tr_tr/customer-service/product-and-quality/ product-sustainability.html adresinden alındı

H\&M. (2020b). https://www2.hm.com/tr_tr/kadin/ozellige-gore-satin-al/16r-garmentcollecting.html adresinden alındı

İnal, A. (2003). Roland Barthes: Bir avant-garde yazarı. İletişim : Araştırmaları, 1(1), 9-38.

Joy, A., Sherry Jr. , J., Venkatesh, A., Wang, J., \& Chan, R. (2012). Fast fashion, sustainability, and the ethical appeal of luxury brands. Fashion Theory, 16(3), 273-295.

Karalar, R., \& Kiracı, H. (2011). Çevresel sorunlara karşı bir çözüm önerisi olarak. Dumlupınar Üniversitesi Sosyal Bilimler Dergisi(30), 63-76.

Koca, E., Öz, C., \& Yıldırım Artaç, B. (2016). Hazır giyim sektöründe sürdürülebilirliğin yöneticiler açısından değerlendirilmesi. Tekstil ve Mühendis, 23(103), 220-230.

Kotler, P., \& Lee, N. (2016). Kurumsal sosyal sorumluluk. İstanbul : MediaCat Kitapları.

Kozlowski, A. (2012). Corporate social responsibility in the apparel industry: A multiple case study analysis (Master Thesis). https://digital.library.ryerson.ca/islandora/ object/RULA\%3A1900 adresinden alındı

Mangır, A. F. (2016). Sürdürülebilir kalkınma için yavaş ve hızlı moda. Selçuk Üniversitesi Sosyal Bilimler Meslek Yüksekokulu Dergisi, 19, 143-154.

Özgen, E. (2007). Kurumsal sosyal sorumluluk kavramı ve çalışan memnuniyetine etkisi. D.Ü. Ziya Gökalp Eğitim Fakültesi Dergisi, 8, 1-6.

Peltekoğlu, F. B. (2018). Halkla ilişkiler nedir? İstanbul: Beta.

Ruşan, T. C. (2019). Bir iletişim dizgesi olarak giyim ve giyime yönelik göstergebilimsel çözümlemelerdeki değişkenler. Erciyes İletişim Dergisi, 6(1), 81-96.

Shen, B. (2014). Sustainable fashion supply chain: Lessons from H\&M. Sustainability, 6(9), 6236-6249.

Shen, B., Zheng, J.-H., Chow, P.-S., \& Chow, K.-Y. (2014). Perception of fashion sustainability in online community. The Journal of The Textile Institute, 105(9), 971-979.

Türkiye Tekstil ve Hazırgiyim Sektöründe Kurumsal Sosyal Sorumluluk Durum Raporu. (2012). https://www.ihkib.org.tr/fp-icerik/ia/d/2017/01/17/mdgfhazirgiyimde-kss-raporu-2012-201701171639340703-1E7D6.pdf adresinden alındı

UN Global Compact. (2020b). https://www.unglobalcompact.org/what-is-gc/ participants/4719-H-M-Hennes-Mauritz-AB adresinden alındı 
UNDP Turkey. (2020a). https://www.tr.undp.org/ adresinden alındı

UNDP Turkey. (2020b). https://www.tr.undp.org/content/turkey/tr/home/sustainabledevelopment-goals.html adresinden alındı

Uzkesici, N. (2005). Kurumsal sosyal sorumluluk: İşletmelerde paydaş beklentilerinin karşılanmasında yeni firsatlar ve tuzaklar. Kurgu Dergisi(21), 69-84.

Waquet, D., \& Laporte, M. (2011). Moda. (I. Ergüden, Çev.) Ankara: Dost Kitabevi Yayınlarl.

Yan, S., \& Ming, F. (2015). Reinterpreting some key concepts in Barthes' theory. Journal of Media and Communication Studies, 7(3), 59-66. 


\title{
Fashion Recycling and Sustainability in the Context of Corporate Social Responsibility: A Semiotic Analysis
}

\author{
Eda Turancı (Asst. Prof. Dr.)
}

\section{Extended Abstract}

The environmental and ecological sensitivity of both individuals and companies is increasing, and the understanding of sustainability is gaining importance. While many situations such as global problems and crises, depletion of natural resources, irreversible disasters in living spaces have played a role in the development of this sensitivity, the sectors that are actors of industrialization have become increasingly conscious about the ecological system and the environment. Among these sectors, especially the fashion industry is a sector where the need for raw materials is intensive, which has negative effects on the environment and natural resources, and various chemicals are used in the production process. The fast-fashion phenomenon, which has become widespread in recent years, has caused more attention to the effects of fashion on the environment.

The concept of fast fashion, on the one hand, ensures that trendy clothes meet the consumer at affordable prices, on the other hand, it points to a system where brands create almost weekly creations to fabricate the latest trends. Besides, this understanding shortens the life of the products and leads to faster consumption of the purchased products. Thus, the need of consumers for new products is constantly continuing.

Due to the ecological effects of the fashion industry, brands are increasingly under pressure to develop their social responsibility awareness and to be environmentally conscious. Corporate social responsibility projects, which are shaped in line with the needs of the society, are also important for brands to reach global standards set in the international arena. In this respect, it is noteworthy that in recent years, projects aimed at protecting the environment and natural resources, providing sustainability, and correcting the negative effects of the sector have been produced in the fashion sector. It is known that important brands of the fast fashion industry are also pioneers in these projects.

The relationship between fashion, sustainability, and recycling is paradoxical. While sustainability aims to slow down consumption, fashion aims at the continuity of consumption. Although the relationship between them is perceived as full of contradictions, it is known that recycling products mean much less use of resources than making new products. For this reason, it is observed that the leading brands of fashion carry out studies such as recycling of the materials they use, waste management, using fewer chemicals and water.

Based on these explanations, two promotional/advertising films within the scope of the "Garment Collecting-Fashion Recycling" project of H\&M, one of the fast fashion brands, were analyzed by semiotics. These films are thought to be important in terms of understanding the social responsibility understanding of the brand, seeing how it transmits the recycling and clothing collection project to the public. The selection of semiotics, which is one of the qualitative research methods, is directly related to the framework of the subject. According to leading theorists in semiotics, fashion is a language in itself, and clothing contains many messages symbolically. It is possible to say 
that fashion itself is a system of indicators. The campaign films selected as samples in the study were analyzed both in the context of "sign, signifier and signified" which are the semantic elements of Saussure, and in the context of "connotation" and "denotation" pointed out by Barthes'.

As a result of the analysis, the following conclusions were reached. In the films, themes such as freedom, entertainment, happiness, peace, self-confidence, being different, hope, living the moment are covered. These themes relate to brand positioning and the target audience of the brand. To explain the positive effects of the campaign on nature and the environment, it has been seen that in the movies, nature images such as trees, forests, grass, lakes, and seas are frequently used. At the same time, it has been seen in films that products belonging to the brand's recycling collection are used. Thus, visual integrity has been created with nature both with the advertisement of the products and with the patterned and soft colors used. In movies, couples or groups of friends are used, and so the message of togetherness is given. Finally, it was seen that more women were given roles in the movies. In the second film examined, it was noted that there were only women, and it was concluded that this was due to the relationship between women and fashion. As a result, the indicators used in promotional films within the scope of corporate social responsibility projects are considered to be functional in terms of creating environmental awareness and awareness among consumers and spreading this awareness to large masses.

Keywords: Corporate Social Responsibility, Fashion, Recycling, Semiotics.

Bu makale intihal tespit yazılımlarıyla taranmıştır. İntihal tespit edilmemiştir.

This article has been scanned by plagiarism detection softwares. No plagiarism detected.

Bu çalışmada "Yükseköğretim Kurumları Bilimsel Araştırma ve Yayın Etiği Yönergesi” kapsamında uyulması belirtilen kurallara uyulmuştur.

In this study, the rules stated in the "Higher Education Institutions Scientific Research and Publication Ethics Directive" were followed. 